\title{
Five decades of radioglaciology
}

\author{
Dustin M. Schroeder ${ }^{1,2}$, Robert G. Bingham ${ }^{3}$, Donald D. Blankenship ${ }^{4}$, \\ Knut Christianson ${ }^{5}$, Olaf Eisen ${ }^{6,7}$ (D), Gwenn E. Flowers ${ }^{8}$ (D), Nanna B. Karlsson ${ }^{9}$ (D), \\ Michelle R. Koutnik ${ }^{5}$, John D. Paden ${ }^{10}\left(\right.$ i) and Martin J. Siegert ${ }^{11}$ (D)
}

\section{Article}

Cite this article: Schroeder DM et al. (2020). Five decades of radioglaciology. Annals of Glaciology 61(81), 1-13. https://doi.org/ 10.1017/aog.2020.11

Received: 2 December 2019 Revised: 11 February 2020 Accepted: 11 February 2020 First published online: 9 March 2020

\section{Keywords:}

glaciological instruments and methods; ground-penetrating radar; radio-echo sounding; remote sensing

\section{Author for correspondence:}

Dustin M. Schroeder, E-mail: dustin.m. schroeder@stanford.edu (c) The Author(s) 2020. This is an Open Access article, distributed under the terms of the Creative Commons Attribution licence (http:// creativecommons.org/licenses/by/4.0/), which permits unrestricted re-use, distribution, and reproduction in any medium, provided the original work is properly cited.
${ }^{1}$ Department of Geophysics, Stanford University, Stanford, USA; ${ }^{2}$ Department of Electrical Engineering, Stanford University, Stanford, USA; ${ }^{3}$ School of GeoSciences, University of Edinburgh, Edinburgh, UK; ${ }^{4}$ Institute for Geophysics, University of Texas, Austin, USA; ${ }^{5}$ Department of Earth and Space Sciences, University of Washington, Seattle, USA; ${ }^{6}$ Alfred-Wegener-Institut, Helmholtz-Zentrum für Polar- und Meeresforschung, Bremerhaven, Germany; ${ }^{7}$ University of Bremen, Bremen, Germany; ${ }^{8}$ Department of Earth Sciences, Simon Fraser University, Vancouver, Canada; ${ }^{9}$ Geological Survey of Denmark and Greenland, Copenhagen, Denmark; ${ }^{10}$ Center for the Remote Sensing of Ice Sheets, University of Kansas, Lawrence, USA and ${ }^{11}$ Grantham Institute, and Department of Earth Science and Engineering, Imperial College London, London, UK

\section{Abstract}

Radar sounding is a powerful geophysical approach for characterizing the subsurface conditions of terrestrial and planetary ice masses at local to global scales. As a result, a wide array of orbital, airborne, ground-based, and in situ instruments, platforms and data analysis approaches for radioglaciology have been developed, applied or proposed. Terrestrially, airborne radar sounding has been used in glaciology to observe ice thickness, basal topography and englacial layers for five decades. More recently, radar sounding data have also been exploited to estimate the extent and configuration of subglacial water, the geometry of subglacial bedforms and the subglacial and englacial thermal states of ice sheets. Planetary radar sounders have observed, or are planned to observe, the subsurfaces and near-surfaces of Mars, Earth's Moon, comets and the icy moons of Jupiter. In this review paper, and the thematic issue of the Annals of Glaciology on 'Five decades of radioglaciology' to which it belongs, we present recent advances in the fields of radar systems, missions, signal processing, data analysis, modeling and scientific interpretation. Our review presents progress in these fields since the last radio-glaciological Annals of Glaciology issue of 2014, the context of their history and future prospects.

\section{Introduction}

Five decades of radioglaciology (the use of radio waves to investigate ice masses of all types) since the first data were published have seen a progression of instruments and platforms, as well as data processing and analysis approaches applied to a growing data archive (e.g. Stern, 1930; Steenson, 1951; Robin, 1975; Gogineni and others, 1998; Dowdeswell and Evans, 2004; Allen, 2008; Turchetti and others, 2008). Radar-sounding (also known as icepenetrating radar) data have been used to observe ice thickness, basal topography and englacial layers across Antarctica and Greenland, as well as many ice caps and glaciers. Major datacollection efforts started in the late 1960s and early 1970s, including a collaboration between the Technical University of Denmark, Scott Polar Research Institute, and National Science Foundation (TUD-SPRI-NSF) to map the bed of Antarctica. Other early surveys were also led by Russia, Germany, Iceland, Italy, China, and Canada (among others) across Antarctica and Greenland, as well as Iceland, Arctic Ice Caps, and mountain glaciers (e.g. Drewry, 1983; Bingham and Siegert, 2007; Björnsson, 2020; Popov, 2020). Planetary radar sounders have also been used, or are planned, to observe the subsurface and near-surface conditions of Mars, Earth's moon, comets and the icy moons of Jupiter (e.g. Seu and others, 2007; Jordan and others, 2009; Kofman and others, 2010; Bruzzone and others, 2013; Kofman and others, 2015; Patterson and others, 2017; Blankenship and others, 2018). Fully exploiting the valuable information from these data, such as ice-sheet bed topography, the distribution of subglacial water, the spatial variation of basal melt, the transition between frozen and thawed bed conditions, englacial temperature, histories of accumulation, flow, and the distribution of age in ice masses remains an active area of international research. In this review paper, and the thematic issue of the Annals of Glaciology on 'Five decades of radioglaciology' to which it belongs, we present recent advances in the field in the context of their history and future prospects. We include papers published in this issue, topics presented at an International Glaciological Society Symposium on the same theme hosted at Stanford University during the summer of 2019, and work added to the published literature since the last thematic Symposium and Annals issue focused on radioglaciology in 2014.

\section{Data}

The data collected by radar surveys in the last five decades have transformed our appreciation of glacier and ice-sheet beds and how ice flows over them. Prior to this era, such information was gained from seismic data, taking orders of magnitude longer to acquire. Early radar 
surveys witnessed significant improvements in survey design, instrument capability (e.g. the Technical University of Denmark System), platforms (e.g. the US Hercules LC-130) and coastal airstrips, leading to systematic surveys of the Greenland and Antarcticice sheets (Sorge, 1933; Robin, 1958; Gudmandsen, 1975; Drewry, 1983). In the case of Antarctica, the TUD-SPRI-NSF collaboration collected over 400000 line-km of data during the 1970s and, in some regions, these data provide the only measurements ever taken. By the early 1980s, those first long-range airborne radar surveys had ended, giving way to regional studies collected by, for example, Russian and German programs and the US Support Office for Aerogeophysical Research (SOAR) in Antarctica (Blankenship and others, 1993; Behrendt and others, 1994; Bell and others, 1998; Hempel and others, 2000; Masolov and others, 2006; Dean and others, 2008; Turchetti and others, 2008). Other examples include surveys of glaciers and ice caps in Iceland, Alpine glaciers, Svalbard and the Russian and Canadian Arctic (e.g. Dowdeswell and others, 1986, 2002, 2004; Björnsson and others, 1996; Fürst and others, 2018; Pritchard and others, 2020).

In the early 2000s, the Bedmap Consortium produced a new compilation of radar data from Antarctica for which the TUD-NSF-SPRI data still formed by far the most significant contribution, with dozens of other regional-scale surveys that form a patchwork coverage of parts of the ice sheet while other regions remained completely free of data (Lythe and Vaughan, 2001). Bedmap2 followed a decade later, including additional regional surveys as well as long- and medium-range airborne studies returned in 2008 by the US-UK-Australia-China-French ICECAP project and NASA's Operation IceBridge (OIB) (Holt and others, 2006; Vaughan and others, 2006; Bell and others, 2011; Young and others, 2011; Ross and others, 2012; Fretwell and others, 2013). However, several regions remained free of data (Pritchard, 2014). Other compilations are now due that will incorporate new data that have been acquired to fill many of Bedmap2's gaps, including, for example, across Marie Byrd Land, West Antarctica, the Recovery Basin/South Pole, the Dome F region and Princess Elisabeth Land, as well as newly remastered TUD-NSF-SPRI film data and updated thickness measurements for the Ross Ice Shelf (Tang and others, 2016; Young and others, 2016; Popov, 2017; Humbert and others, 2018; Jordan and others, 2018a; Karlsson and others, 2018; Morlighem and others, 2019; Paxman and others, 2019; Schroeder and others, 2019; Tinto and others, 2019). Compared to Antarctica, surveys of Greenland starting in the 1990 s by the University of Kansas as part of NASA's Program for Arctic Regional Climate Assessment (PARCA) and later OIB have led to relatively abundant and mutually interpretable observations of the ice-sheet bed and englacial properties (Bamber and others, 2013; Gogineni and others, 2014; MacGregor and others, 2015a; Morlighem and others, 2017).

In addition to the collection of radar sounding profiles, interpolation is a critical component of producing bed topography maps. Previous approaches focused on grid interpolation techniques such as spline interpolation or kriging (e.g. Fretwell and others, 2013). However, in many regions, this gridded topography falls short of capturing topography at the scales most critical for resolving ice-flow processes (Durand and others, 2011; King and others, 2016; Bingham and others, 2017; Kyrke-Smith and others, 2018). For this reason, other approaches, such as massconservation modeling or geostatistical approaches, which can provide multiple observation-consistent realizations, provide improved interpolations of bed topography (e.g. Rasmussen, 1988; Warner and Budd, 2000; Goff and others, 2014; Morlighem and others, 2017; MacKie and others, 2019).

Future surveys are unlikely to resemble those conducted previously since ice-sheet models require that data are collected with strategies optimized for their purpose, including flowlines for process interpretation, ground-based time-series for local process monitoring, and repeat flights (Kingslake and others, 2014; Nicholls and others, 2015; Chu and others, 2016; Khazendar and others, 2016; Holschuh and others, 2017; Davies and others, 2018; Schroeder and others, 2018; Young and others, 2018; Bartlett and others, 2020). These process- and site-specific surveys can also take advantage of systems with wider bandwidths and larger antenna arrays that provide enhanced performance, but with more limited range (e.g. Rodriguez-Morales and others, 2013; Kjær and others, 2018). Ultimately, new platforms, such as rovers, drones and satellites stand to transform the way radarsounding observations are made (Jezek and others, 2006; Koh and others, 2010; Arcone and others, 2016; Freeman and others, 2017; Dall and others, 2018; Carrer and others, 2018; Gogineni and others, 2018; Culberg and Schroeder, 2019; Arnold and others, 2020).

\section{Systems}

Early radar sounding systems spanned a range of frequency, bandwidth, power and array configurations including both short mono-pulse and chirped-waveform systems (Allen, 2008; Gärtner-Roer and others, 2014). However, until the 1990s (and the availability of faster and lower-cost electronics) the data recorded remained 'incoherent', limiting the azimuth resolution and processing gain below that achievable with phase-coherent stacking and Synthetic Aperture Radar (SAR) processing (Musil and Doake, 1987; Hamran and Aarholt, 1993; Leuschen and others, 2000; Legarsky and others, 2001; Hélière and others, 2007; Peters and others, 2007). For stationary ground-based systems, a similar gain in the achievable post-processing signal tonoise ratio (SNR) and range-estimate precision has been achieved by coherent 'phase-sensitive' frequency-modulated continuous wave (FMCW) radars (Nicholls and others, 2015).

Just as coherent radar sounders enabled improved along-track resolution and processing gain, the development of systems with multi-channel cross-track arrays improved cross-track resolution, processing gain, clutter discrimination and swath mapping (Gogineni and others, 1998; Paden and others, 2010; Wu and others, 2011; Rodriguez-Morales and others, 2013; Castelletti and others, 2017; Holschuh and others, 2020; Scanlan and others, 2020). This is also true for ground-based multiple input, multipleoutputimplementations of the 'phase-sensitive' FMCW radars mentioned above (Young and others, 2018). While these multi-channel sounders do achieve some diversity in viewing angle and englacial propagation, true bistatic observations and tomographic inversions can be exploited to provide much richer constraints on subsurface properties including, for example, using commercial pulsed groundpenetrating radar (GPR) systems in common mid-pointor borehole configurations to achieve wider (though coherence-limited) offsets (e.g. Kofman and others, 2015; Holschuhand others, 2016; Patterson and others, 2017; Church and others, 2019).

The evolution of distinct radar sounding systems has resulted in a diversity of frequencies, spanning $\mathrm{HF}(3-30 \mathrm{MHz})$, VHF (30$300 \mathrm{MHz})$, UHF (300 MHz-3 GHz) and higher frequency bands (Gudmandsen, 1975; Paden and others, 2005; Hélière and others, 2007; Peters and others, 2007; Allen, 2008; Shi and others, 2010; Hindmarsh and others, 2011; Rignot and others, 2013; Rodriguez-Morales and others, 2013; Dall and others, 2018; Yan and others, 2018). Although, this diversity can make it challenging to compare or combine distinct datasets, it also offers the opportunity to probe the radio-frequency responseof the ice sheet to constrain conditions and processes with greater fidelity (e.g. Carrer and Bruzzone, 2017; Winter and others, 2017).

In addition to systems capable of recording amplitude, phase and channel information, radar sounder development has also 
included systems that record multiple polarizations (e.g. Vaughan and others, 2006; Dall and others, 2010). These systems allow for the analysis of crystal-fabric orientation from polarization information (Doake and others, 2002; Fujita and others, 2003; Matsuoka and others, 2003; Eisen and others, 2007; Drews and others, 2012; Li and others, 2018; Wang and others, 2018; Jordan and others, 2019). This information can be used to constrain the depth distribution of the crystal orientation fabric along survey lines, enabling the investigation of processes occurring in ice masses, comparison to ice-dynamic models, and interpretation of particle-astrophysical observations (e.g. Jordan and others, 2019, 2020a,b; Shoemaker and others, 2020).

Technical advances in available hardware have also allowed the development of stationary systems designed for long-term (several months to years) autonomous operation with repeated observations over cycles ranging from minutes to days, targeting the temporal evolution of a particular site (Nicholls and others, 2015; Kendrick and others, 2018; Mingo and others, 2020; Vankova and others, 2020). To further address the power demands of generating an active radar signal (particularly in the extreme resource constraints of planetary missions) passive radar sounding is also being developed as a new radioglaciological technique to exploit Jovian radio noise, or that from the Sun, as sources for radio echo detection, with the promise to enable pervasive monitoring of subsurface conditions by low-cost, low-power sensor networks (Romero-Wolf and others, 2015, 2016; Schroeder and others, 2016b; Peters and others, 2018).

\section{Processing}

Processing radar-sounding data turns low-SNR, low-resolution, high-clutter raw data into usable radargrams. With the exception of a subset of short-pulse systems such as commercial GPRs and some legacy sounders still in use today nearly all radar sounder processing begins with pulse-compression of a chirped waveform using some windowing function for range-sidelobe suppression, some amount of on-board pre-summing to increase SNR and moderate data-rates, and filtering (e.g. Peters and others, 2007; Booth and others, 2010; Lilien and others, 2020; Wang and others, 2020). For coherent radar-sounding data, along-track SAR focusing is also nearly ubiquitous to improve the SNR, signal to clutter ratio and azimuth resolution (Legarsky and others, 2001; Hélière and others, 2007; Peters and others, 2007). Additionally, azimuth processing that evaluates along-track coherence, multiple apertures, large coherent apertures, layerspecific phase histories, or squinted processing, enhance layer resolution or provide information about the scattering function and fine-scale geometry of the bed (e.g. Oswald and Gogineni, 2008; Schroeder and others, 2014a; Heister and Scheiber, 2018; Castelletti and others, 2019; Ferro, 2019). For multi-channel sounders, cross-track processing can considerably increase the level of resolution, with large benefits for tomographic swath imaging of the ice bottom and internal structure, in particular of irregular disturbances of basal ice, such as folds or entrained matter (e.g. Paden and others, 2010; Wu and others, 2011; Rodriguez-Morales and others, 2013; Castelletti and others, 2017; Young and others, 2018).

In addition to the instantaneous or single-survey coherence required for focusing and array processing, modern high-stability and low-noise systems make it feasible to perform repeat-pass interferometric analysis on sounding data from ground-based platforms (Kingslake and others, 2014; Nicholls and others, 2015). While point-based observations of phase changes over time periods, ranging from months to years, are now widespread, for example, to deduce basal melt rates of ice shelves and vertical velocities in ice sheets, its spatial application to large airborne surveys is relatively recent and, as yet, rarely applied (e.g. Corr and others, 2002; Castelletti and Schroeder, 2017; Stewart and others, 2019).

Another critical area of innovation in radioglaciological data processing and analysis is automatic methods for radargram image interpretation. These include algorithms for layer tracking, bed and surface mapping and basal feature categorization (Sime and others, 2011; Crandall and others, 2012; Ferro and Bruzzone, 2012; Ilisei and Bruzzone, 2015; Panton and Karlsson, 2015; Carrer and Bruzzone, 2016; Rahnemoonfar and others, 2017; Berger and others, 2018; Donini and others, 2019). Success of these approaches is a prerequisite to be able to cope efficiently with the data volume of future surveys and effectively exploit their information content.

\section{Ice sheet and glacier bed conditions}

Five decades of radioglaciology have produced a diverse array of information pertaining to subglacial conditions. The vast majority of surveys have been motivated by the primary imperative of locating the bed reflector either to estimate the total volume and sea-level potential of the major ice sheets or to map basal topography (e.g. Bailey and others, 1964; Gudmandsen, 1969; Bamber and others, 2013; Fretwell and others, 2013). In the last two decades, the emphasis has expanded to the investigation of the geometric, thermal and material properties of the basal interface, by using the sounder-appropriate radar equation to solve for either basal reflectivity or echo character (Peters and others, 2005; Oswald and Gogineni, 2008; Schroeder and others, 2013; Grima and others, 2014b; Haynes and others, 2018b; Haynes, 2020).

Radar sounding data encode a range of information about the roughness of the basal interface. The most common glaciological definition of roughness is the extent to which terrain varies vertically over a given horizontal distance (Rippin and others, 2014). As mapped across a number of regions of Antarctica and Greenland, roughness variations at the multi-kilometer scale inform us about present and past ice-stream and ice-stream tributary locations (Siegert and others, 2004; Bingham and Siegert, 2007, 2009; Rippin and others, 2014; Frank and others, 2020). Additionally, basal roughness at the wavelength-scale can affect the character of the reflected echo including its specularity (or spread in Doppler), waveform abruptness, statistical distribution of echo amplitudes, as well as the radar-derived topography itself (Goff and others, 2014; Grima and others, 2014a; Rippin and others, 2014; Schroeder and others, 2014a; Jordan and others, 2017; Heister and Scheiber, 2018; Eisen and others, 2020; Franke and others, 2020; King, 2020). Principles from these studies have also been translated to paleoglacial landscapes and have also been compared to contemporary bed morphology and lithology (Gudlaugsson and others, 2013; Schroeder and others, 2014c; Falcini and others, 2018; Cooper and others, 2019; Muto and others, 2019; Holschuh and others, 2020).

In radioglaciology, although reflectivity is used as an umbrella term encompassing all methods used to interrogate variations in the magnitude of the bed echo, it most commonly and appropriately refers to changes in the material properties (and therefore Fresnel reflection coefficient) of the ice-bed interface (Peters and others, 2005). While there are challenges in correcting or constraining attenuation or surface roughness losses, the basal thermal state (frozen or thawed and the presence or absence of water) fundamentally affects the reflection coefficient (Peters and others, 2005; Matsuoka, 2011; Schroeder and others, 2016a). The reflection coefficient can provide a constraint on where the bed is frozen or thawed, the reach and character of ocean water at the grounding line, and basal conditions of ice streams (Peters and others, 2005; Jacobel and others, 2009; Ashmore and others, 2014; Christianson and others, 2016). The presence and volume of inferred basal water bodies have also 
been used to place constraints on the basal thermal state and/or geothermal flux, while layer drawdown has also been used to constrain basal melt rates and geothermal flux (Fahnestock and others, 2001; Catania and others, 2006; Buchardt and Dahl-Jensen, 2007; Schroeder and others, 2014b; Rezvanbehbahani and others, 2017, 2019; Seroussi and others, 2017; Jordan and others, 2018a,b).

Perhaps the most widely and successfully studied basal feature with radar sounding data has been subglacial water bodies, particularly subglacial lakes in Antarctica using the principle that subglacial water results in reflections brighter than surrounding bed echoes in radar data (Oswald and Robin, 1973; Peters and others, 2005; Wright and Siegert, 2012). Because of the coherent specular character of subglacial water, small fractional areas can dominate the echo both in terms of reflectivity and geometric spreading (Haynes and others, 2018b). This has been exploited to automatically detect lakes in radar sounding data (Carter and others, 2007; Ilisei and others, 2018). Additionally, lake-bottom echoes have been used to probe water thickness and conductivity (Gorman and Siegert, 1999). Surface altimetry data have also been used to infer active lakes around Antarctica where the ice surface has been observed to rise and fall, yet, surprisingly, these lakes typically do not have higher reflectivities than their surroundings in radar data, showing that we still have much to learn about Antarctic subglacial lakes (Carter and others, 2007; Smith and others, 2009; Siegfried and others, 2016; Carter and others, 2017; Siegert, 2018). This is also emphasized by different observations with different systems of the same regions, leading to contrasting interpretations (e.g. Bell and others, 2007; Humbert and others, 2018). Recent advances in the analysis of subglacial hydrology from radar sounding data has focused on subglacial water systems beyond Antarctic subglacial lakes (e.g. Young and others, 2016). This includes utilizing bed-echo strength and character to investigate water body geometry and dynamic configuration, catchment-scale drainage systems and grounding zones (Schroeder and others, 2013, 2014a; Ashmore and Bingham, 2014; Christianson and others, 2016). In Greenland, a range of studies has investigated the distribution of subglacial water, including lakes, topographically controlled seasonal storage and gradients in water near the onset of fast flow (Oswald and Gogineni, 2008; Palmer and others, 2013; Chu and others, 2016, 2018b; Jordan and others, 2018b; Oswald and others, 2018; Bowling and others, 2019). Hypersaline lakes have also been identified beneath Devon Ice Cap in Arctic Canada (Rutishauser and others, 2018).

\section{Radio-wave attenuation}

Laboratory analyses of radio-wave absorption in ice, as well as radar sounding data from the field, have revealed that while relatively homogeneous ice is a very low-loss medium for radio-waves at VHF frequencies, there is a loss of returned power englacially due to dielectric absorption of radiowaves in ice. Dielectric absorption is proportional to the electrical conductivity of the ice, which is related to ice temperature and the presence of impurities (Glen and Paren, 1975; Johari and Charette, 1975; Moore and Fujita, 1993; Stillman and others, 2013; Pettinelli and others, 2015). Without sufficiently distinct basal echo signals (e.g. relative changes that delineate sharp boundaries, such as ice stream shear margins) or sufficiently effective corrections, uncertainty in englacial attenuation can obfuscate the interpretation of basal reflectivities (Matsuoka, 2011; Siegert and others, 2016; Schroeder and others, 2016a).

Empirical methods for estimating englacial attenuation using bed echoes range from simple linear fitting to adaptive or model-informed fitting (Jacobel and others, 2009; Wolovick and others, 2013; Ashmore and others, 2014; Jordan and others, 2016; Schroeder and others, 2016c). Englacial layers themselves have also been used to derive attenuation (Matsuoka and others,
2010; MacGregor and others, 2015b). These approaches can also be intercompared or combined (e.g. Hills and others, 2020; Jeofry and others, 2020). Additionally, investigating attenuation with variable offset can constrain englacial, attenuation, though there is a limit on the maximum offset achievable with commercial GPR systems (Holschuhand others, 2016). These empirical attenuation values can either be used to correct losses to enable reflectivity interpretation or interpreted themselves as a proxy for englacial temperature.

In addition to applying empirical methods that estimate and correct for attenuation, attenuation rate can also be modeled (Matsuoka and others, 2012). This approach can be used when correcting attenuation effects or constraining the bed conditions using layer power (MacGregor and others, 2015b; Chu and others, $2018 b$ ). Modeled attenuation can be compared to observations to constrain englacial temperature, parameterize basal conditions to match surface velocities or to quantify englacial water from persistent firn aquifers (Forster and others, 2014; Schroeder and others, 2016c; Chu and others, 2018a; Holschuh and others, 2019).

\section{Englacial structure}

The study of radar-derived englacial properties dates back almost to the beginning of radioglaciology (e.g. Harrison, 1973; Gudmandsen, 1975; Paren and Robin, 1975). The englacial information that radar data contain has the potential to provide insights into ice-flow processes as well as climatic forcings. The layers have thus been widely used with models for ice-core site selection, stratigraphic control and inferring accumulation histories (see below) (e.g. Jacobel and Hodge, 1995; Cavitte and others, 2016; Parrenin and others, 2017). In recent years, the radioglaciological community has seen an increase in the retrieval of such information from radar data although barriers remain to the widespread usage of englacial stratigraphy. This is due to the fact that a substantial amount of manual work is generally needed to convert the stratigraphic information into, for example, dated isochrone surfaces that can readily be used by ice-flow models. Attempts to overcome this obstacle include methodologies focusing on quantifying the slope of the stratigraphy and extracting information from slopes instead (Panton and Karlsson, 2015; Holschuh and others, 2017; Castelletti and others, 2019). Studies focusing on the reorganization of ice flow often avoid tracing isochrones and take a qualitative approach. For example, imprints of shear margin migration or change in flow direction are typically identified based on the amount of stratigraphic disruption. Examples include studies showing changes in ice-flow structure or folded stratigraphy in Greenland and entrained debris in a glacier in Patriot Hills, West Antarctica (Catania and others, 2006; Martín and others, 2009; Dahl-Jensen and others, 2013; Bell and others, 2014; Bingham and others, 2015; Kingslake and others, 2016; Winter and others, 2019; Ross and Siegert, 2020). Advances in processing radargrams to extract ice-sheet structure make it possible to interpret these features in regions of complex flow (Elsworth and others, 2020).

The tracing of englacial isochrones in the radar data acquired over Greenland between 1993 and 2013 by the University of Kansas Center for Remote Sensing of Ice Sheets and OIBis a vital step forward in the efforts to make englacial stratigraphic information readily available (Gogineni and others, 1998, 2001; MacGregor and others, 2015a; Arnold and others, 2018). The resulting data archive has increased the availability of traced isochrones by orders of magnitude. Derived results include evidence of Holocene deceleration of the Greenland ice sheet, and improved constraints on its internal temperature (MacGregor and others, 2015b, 2016). In Antarctica, no such large-scale synthesis has been undertaken, but the SCAR AntArchitecture 
project has the potential to address this critical gap. Several studies have successfully linked isochrones between deep ice-core sites: the interior Antarctic ice-core sites are now linked from Dome Concordia through Vostok to Dome Argus, and Dome Fuji has been linked to the EPICA-DML (European Project for Ice Coring in Antarctica Dronning Maud Land) ice-core site (Cavitte and others, 2016; Winter and others, 2019). These efforts will play a key role in identifying optimal drill sites for the Oldest Ice (ice older than 1.5 million years, Fischer and others, 2013).

Other important derived products from traced isochrones are the past accumulation rates and patterns (e.g. Eisen, 2008). Recent work in this area has been carried out on time-scales ranging from annual to centennial to millennial (Eisen and others, 2008; Medley and others, 2014; Nielsen and others, 2015; Grima and others, 2016; Karlsson and others, 2016; Koenig and others, 2016; Koutnik and others, 2016; MacGregor and others, 2016; Lewis and others, 2017; Cavitte and others, 2018; Karlsson and others, 2020; Montgomery and others, 2020). Efforts to automate layer tracing continue, which include methodologies that use seed points to initiate semi-automatic tracing routines as well as fully automatic schemes. In parallel, the extra-terrestrial radar community has been working toward automatically extracting layer information from the Martian orbital radar sounders (Ferro and Bruzzone, 2012; Onana and others, 2015; Xiong and others, 2018; Xiong and Muller, 2019). Delf and others (2020) (this issue) present some strategies for assessing automated algorithms inherited from both terrestrial and planetary work.

\section{Interpretation}

The history and dynamics of glaciers and ice sheets are written into radar-sensitive properties of these ice masses. Interpretation of radar data may be qualitative or quantitative, with the latter facilitated by process-based models in particular. In its most common form, however, interaction between radioglaciology and models is often limited and one-directional: radio-echo sounding of ice depth furnishes the basal boundary condition for ice-flow models (e.g. Fretwell and others, 2013). While gaps in our knowledge of basal topography have spurred model development, radar studies have produced a trove of other data and discoveries, including, for example, evidence of retreat, past flow, basal accretion, firn-aquifers and ice-shelf conduits, that remain under-exploited by theory and models (Conway and others, 1999; Siegert and others, 2004; Bingham and Siegert, 2007; Bell and others, 2011; Morlighem and others, 2011; Forster and others, 2014; Bons and others, 2016; Drews and others, 2017; Jordan and others, 2018a; Leysinger Vieli and others, 2018; Holschuh and others, 2019; Langhammer and others, 2019).

Theoretical work has established relationships between the architecture of internal layers and ice-sheet accumulation, topography, rheology and dynamics (e.g. Nereson and Waddington, 2002; Siegert, 2003; Hindmarsh and others, 2006; Parrenin and others, 2006; Martín and others, 2009; Felix and King, 2011). Internal layers have been integrated with models to determine ice rheology and to understand flow history, including migration of ice streams, divides and domes (e.g. Nereson and Raymond, 2001; Ng and Conway, 2004; Catania and others, 2006; Gillet-Chaulet and others, 2011; Pettit and others, 2011; Drews and others, 2015; MacGregor and others, 2016). The discovery of deep internal structures that do not conform to the bed has prompted new model exploration of englacial and basal processes including interpretation of their radar scattering character, with implications for interpreting ice-sheet dynamics and the climate archive (e.g. Bell and others, 2011, 2014; Dahl-Jensen and others, 2013; Wolovick and others, 2013; Wrona and others, 2017; Kjær and others, 2018; Goldberg and others, 2020).
In addition to englacial layers, radar sounding data have been used to detect channels under ice shelves that have also been the focus of a suite of model investigations (e.g. Jenkins, 2011; Le Brocq and others, 2013; Sergienko, 2013; Drews, 2015; Alley and others, 2016). Theory and observation are yielding new insight into ice-ocean interactions and real-time geomorphic processes in grounding zones, the influence of topography on channel position and formation, and the uncertain relationship between channels and ice-shelf stability (e.g. Gladish and others, 2012; Greenbaum and others, 2015; Khazendar and others, 2016; Drews and others, 2017; Gourmelen and others, 2017; Jeofry and others, 2018).

With so much radioglaciological data, the advent of resources such as ice-sheet-wide radiostratigraphic archives should help operationalize data-model integration (MacGregor and others, 2015a). But how are such archives best exploited? Inverse methods present a natural approach, although the persistent problem of non-uniqueness demands care in defining the problem, choosing the tools and incorporating constraints (e.g. Waddington and others, 2007; Eisen, 2008; Gudmundsson, 2011; Koutnik and Waddington, 2012; Nielsen and others, 2015; Koutnik and others, 2016). Computational costs of large-scale models further demand attention to efficiency, for example, by the use of adjoint methods (e.g. Hascoët and Morlighem, 2018). Consideration should also be given to the information content of different variables, including those sensitive to basal processes, as well as to the limitations of rendering 3-D effects in 2-D data (Leysinger-Vieli and others, 2007; Holschuh and others, 2017; Young and others, 2018). While we must devise modeling strategies to make best use of the data, this is far from a case of models simply lagging observations. Challenges remain in combining disparate datasets, conditioning data for comparison with modeling and utilizing radiometric, interferometric and polarimetric information in modeling (e.g. Hindmarsh and others, 2009; Schroeder and others, 2016c; Castelletti and others, 2017, 2019; Winter and others, 2017, 2019; Chu and others, 2018b; Jordan and others, 2019). Finally, data-model interaction is a two-way street: testable hypotheses produced by theory and models may suggest new observational targets or provide new reasons to tap the rich radioglaciological archive (e.g. Raymond, 1983; Arthern and others, 2015).

\section{Planetary radioglaciology}

The bulk of extra-terrestrial ice-sounding data stems from the planet Mars, specifically from the two orbital radar sounders: MARSIS (Mars Advanced Radar for Subsurface and Ionospheric Sounding) onboard the European Space Agency's Mars Express, and SHARAD onboard the Mars Reconnaissance Orbiter launched by NASA (National Aeronautics and Space Administration, USA) (SHAllow RADar, Seu and others, 2007; Jordan and others, 2009). The difference in frequency between the two sounders allowed for different penetration depths and thereby different insights into the planet's ice bodies (MARSIS operated at $1.3-5.5 \mathrm{MHz}$ in its subsurface sounding mode while SHARAD used 15-25 MHz). Although both instruments are now inactive, analysis of the data is ongoing and continues to contribute to our understanding of water ice on Mars. The results from the radar sounders documented the high water content of the Martian water-ice reservoirs (e.g. Grima and others, 2009). These have now been supplemented by more detailed studies of the composition of the polar ice bodies, the immediate subsurface of the north pole, and the mid-latitude water ice reservoirs (Guallini and others, 2018; Mirino and others, 2018; Petersen and others, 2018; Putzig and others, 2018; Nerozzi and Holt, 2019). In addition, the radar sounding has confirmed areas on 
the planet also contains significant volumes of buried water ice (Bramson and others, 2015; Stuurman and others, 2016). One of the most prominent findings is the discovery of a signal that shares similarities with those of a liquid water body (Orosei and others, 2018). In the MARSIS data, this proposed 'subglacial lake' has characteristically bright and specular reflections and was found $1.8 \mathrm{~km}$ below the South Polar Layered Deposits. The salt content and/or heat flux necessary to form and sustain such a lake is, however, still debated (Sori and Bramson, 2019). In addition to these findings, the radar data have successfully been utilized to gain insights into the glaciological and climatological processes on the planet, including the deformational properties of Martian water ice, and the past climate history and accumulation patterns of both the North Polar Layered Deposits and the South Polar Layered Deposits (Karlsson and others, 2015; Parsons and Holt, 2016; Smith and others, 2016; Whitten and others, 2017; Nerozzi and Holt, 2018; Lalich and others, 2019; Schmidt and others, 2019). The radar data have also been used to reconcile observations from visual imagery with the radar-imaged englacial stratigraphy (Christian and others, 2013; Lalich and Holt, 2017).

Moving further afield, two radar sounders are now under preparation to probe the subsurface of the Jovian system. Two instruments have been selected for upcoming missions to Ganymede and Europa: the $9 \mathrm{MHz}$ frequency Radar for Icy Moons Exploration (RIME) instrument on board the European Space Agency's Jupiter Icy Moons Explorer (JUICE) and the 9 and $60 \mathrm{MHz}$ frequency Radar for Europa Assessment and Sounding: Ocean to Near-surface (REASON) instrument on board NASA's Europa Clipper (Bruzzone and others, 2013; Pappalardo and others, 2015; Lorente and others, 2017; Blankenship and others, 2018). These sounders are designed to probe the moons' interiors and have penetration depths which are functions of surface roughness, volume scattering, ice-shell thermal structure, chemistry and the character of the ice/water interface (Moore, 2000; McKinnon, 2005; Blankenship and others, 2009; Bruzzone and others, 2011; Schmidt and others, 2011; Berquin and others, 2013; Grima and others, 2014b; Pettinelli and others, 2015; Di Paolo and others, 2016; Grima and others, 2016; Aglyamov and others, 2017; Heggy and others, 2017; Kalousová and others, 2017; Campbell and others, 2018; Gerekos and others, 2018; Michaelides and Schroeder, 2019; Culha and others, 2020). The addition of a dual-channel VHF band on REASON also allows for characterization of the European ionosphere, altimetric investigation of Europa's shell and tides, and dual-frequency or interferometric clutter discrimination (Grima and others, 2015; Carrer and Bruzzone, 2017; Castelletti and others, 2017; Haynes and others, 2018a; Steinbrügge and others, 2018; Scanlan and others, 2019). Finally, the ability of both instruments to record strong Jovian emissions raises the possibility of using those emissions to probe the ice shell using passive radio sounding (Romero-Wolf and others, 2015; Schroeder and others, 2016b; Peters and others, 2018).

In addition to Mars and the icy Jovian Moons, radar sounding is also being deployed to investigate ice on other planetary bodies. For example, NASA's Lunar Reconnaissance Orbiter was equipped with a radar sounder in the gigahertz frequency range in order to search for water ice on Earth's moon (Nozette and others, 2010). The data reveal the existence of large deposits of relatively clean ice in the polar regions (Spudis and others, 2013). Unfortunately, measurements temporarily discontinued after an instrument failure in 2011, but have resumed in a bi-static configuration (Patterson and others, 2017). Additionally ESA's Rosetta mission included the bistatic CONSERT experiment (COmet Nucleus Sounding Experiment by Radiowave Transmission), which performed the first tomographic imaging of the interior of a comet (Glassmeier and others, 2007; Kofman and others, 2015).

\section{Conclusions}

More than 50 years after the first collection of radioglaciological observations, radar-sounding data are being acquired over ice sheets, glaciers, ice shelves and ice shells across the solar system at unprecedented scales and rates. Terrestrially, this ever growing data volume, along with re-mastery of archival data, is enabling multi-temporal investigations of subglacial and englacial processes at the spatial and temporal scales relevant to ice-sheet and sealevel change. Recent advances in radar-sounder systems now allow for the acquisition of multi-frequency, multi-offset, polarimetric and interferometric data that can provide rich new information about conditions within and beneath the ice. At the same time, advances in data analysis, interpretation and modeling have paved the way for using that rich new information to investigate the fundamental physical processes that control the past, present and future evolution of ice masses. Additionally, recent progress in sensor and platform technologies is making it possible to move from mapping to monitoring approaches in radarsounding surveys by exploiting low-cost radar-sounder sensor networks, autonomous rovers and drones, or even orbital sounding. Finally, planetary ice/water systems are only growing in their appeal and feasibility as targets of radio-echo sounding. After half a century, radioglaciology may just be entering its golden age.

Acknowledgments. We would like to thank Ala Khazendar for serving as the Scientific Editor and Hester Jiskoot for serving as Associate Chief Editor for this manuscript. We would also like to thank Joe MacGregor and two anonymous reviewers for their thoughtful feedback on the manuscript.

\section{References}

Aglyamov Y, Schroeder DM and Vance SD (2017) Bright prospects for radar detection of Europa's ocean. Icarus 281, 334-337. doi: 10.1016/j.icarus. 2016.08.014.

Allen C (2008) A brief history of radio-echo sounding of ice. Earthzine. Available at: https://earthzine.org/a-brief-history-of-radio-echo-soundingof-ice-2/.

Alley KE, Scambos TA, Siegfried MR and Fricker HA (2016) Impacts of warm water on Antarctic ice shelf stability through basal channel formation. Nature Geoscience 9(4), 290-294. doi: 10.1038/ngeo2675.

Arcone SA and 5 others (2016) Ground-penetrating radar profiles of the McMurdo Shear Zone, Antarctica, acquired with an unmanned rover: interpretation of crevasses, fractures, and folds within firn and marine ice GPR profiles of the McMurdo shear zone. Geophysics 81(1), WA21-WA34. doi: 10.1190/geo2015-0132.1.

Arnold E and 9 others (2018) HF/VHF radar sounding of ice from manned and unmanned airborne platforms. Geosciences 8(5), 182. doi: 10.3390/ geosciences 8050182 .

Arnold E, Leuschen C, Paden J, Hale R and Keshmiri S (2020) CReSIS airborne radars and platforms for ice and snow sounding. Annals of Glaciology 61(81), 58-67. doi: 10.1017/aog.2019.37.

Arthern RJ, Hindmarsh RC and Williams CR (2015) Flow speed within the Antarctic ice sheet and its controls inferred from satellite observations. Journal of Geophysical Research: Earth Surface 120(7), 1171-1188. doi: 10.1002/2014JF003239.

Ashmore DW and Bingham RG (2014) Antarctic subglacial hydrology: current knowledge and future challenges. Antarctic Science 26(6), 758-773. doi: 10.1017/S0954102014000546.

Ashmore DW, Bingham RG, Hindmarsh RC, Corr HF and Joughin IR (2014) The relationship between sticky spots and radar reflectivity beneath an active West Antarctic ice stream. Annals of Glaciology 55(67), 29-38. doi: 10.3189/2014AoG67A052.

Bailey J, Evans S and Robin GdQ (1964) Radio echo sounding of polar ice sheets. Nature 204(4957), 420-421. doi: 10.1038/204420a0.

Bamber J and 10 others (2013) A new bed elevation dataset for Greenland. The Cryosphere 7, 499-510. doi: 10.5194/tc-7-499-2013.

Bartlett OT and 5 others (2020) Geospatial simulations of airborne ice-penetrating radar surveying reveal elevation under-measurement bias for ice sheet bed topography. Annals of Glaciology 61(81), 46-57. doi: 10.1017/aog.2020.35. 
Behrendt JC and 6 others (1994) CASERTZ aeromagnetic data reveal late Cenozoic flood basalts (?) in the West Antarctic rift system. Geology 22(6), 527-530. doi: 10.1130/0091-7613(1994)022<0527:CADRLC >2.3.CO;2.

Bell RE and 6 others (1998) Influence of subglacial geology on the onset of a West Antarctic ice stream from aerogeophysical observations. Nature 394(6688), 58-62. doi: 10.1038/27883.

Bell RE and 9 others (2011) Widespread persistent thickening of the east Antarctic ice sheet by freezing from the base. Science (New York, N.Y.) 331(6024), 1592-1595. doi: 10.1126/science.1200109.

Bell RE and 8 others (2014) Deformation, warming and softening of Greenland's ice by refreezing meltwater. Nature Geoscience 7, 497-502. doi: 10.1038/ngeo2179.

Bell RE, Studinger M, Shuman CA, Fahnestock MA and Joughin I (2007) Large subglacial lakes in East Antarctica at the onset of fast-flowing ice streams. Nature 445(7130), 904-907. doi: doi.org/10.1038/nature05554.

Berger V and 5 others (2018) Automated tracking of 2D and 3D ice radar imagery using viterbi and TRW-S. In IGARSS 2018-2018 IEEE International Geoscience and Remote Sensing Symposium. IEEE, pp. 4162-4165. doi: 10.1109/IGARSS.2018.8519411.

Berquin Y, Kofman W, Herique A, Alberti G and Beck P (2013) A study on Ganymede's surface topography: perspectives for radar sounding. Planetary and Space Science 77, 40-44. doi: 10.1016/j.pss.2012.07.004.

Bingham RG and 9 others (2015) Ice-flow structure and ice dynamic changes in the Weddell Sea sector of West Antarctica from radar-imaged internal layering. Journal of Geophysical Research: Earth Surface 120(4), 655-670. doi: 10.1002/2014JF003291.

Bingham RG and 9 others (2017) Diverse landscapes beneath Pine Island Glacier influence ice flow. Nature Communications 8(1), 1618. doi: 10.1038/s41467-017-01597-y.

Bingham RG and Siegert MJ (2007) Radio-echo sounding over polar ice masses. Journal of Environmental and Engineering Geophysics 12(1), 47-62. doi: 10.2113/JEEG12.1.47.

Bingham RG and Siegert MJ (2009) Quantifying subglacial bed roughness in Antarctica: implications for ice-sheet dynamics and history. Quaternary Science Reviews 28(3-4), 223-236. doi: 10.1016/j.quascirev.2008.10.014.

Björnsson H and 6 others (1996) The thermal regime of sub-polar glaciers mapped by multi-frequency radio-echo sounding. Journal of Glaciology 42(140), 23-32. doi: 10.3189/\$0022143000030495.

Björnsson H and Pálsson F (2020) Radio-echo soundings on Icelandic temperate glaciers: history of techniques and findings. Annals of Glaciology $\mathbf{6 1}$ (81), 25-34. doi: 10.1017/aog.2020.10.

Blankenship DD and 5 others (1993) Active volcanism beneath the West Antarctic ice sheet and implications for ice-sheet stability. Nature 361(6412), 526-529. doi: 10.1038/361526a0.

Blankenship DD and 5 others (2018) Reason for Europa. In 42nd COSPAR Scientific Assembly, Vol. 42, Pasadena, CA.

Blankenship DD, Young DA, Moore WB and Moore JC (2009) Radar sounding of Europa's subsurface properties and processes: the view from Earth. In Europa. Tucson: University of Arizona Press, pp. 631-654.

Bons PD and 10 others (2016) Converging flow and anisotropy cause large-scale folding in Greenland's ice sheet. Nature Communications 7. doi: $10.1038 /$ ncomms 11427 .

Booth AD, Clark R and Murray T (2010) Semblance response to a groundpenetrating radar wavelet and resulting errors in velocity analysis. Near Surface Geophysics 8(3), 235-246. doi: 10.3997/1873-0604.2010008.

Bowling J, Livingstone S, Sole A and Chu W (2019) Distribution and dynamics of Greenland subglacial lakes. Nature Communications 10(1), 1-11. doi 10.1038/s41467-019-10821-w.

Bramson AM and 6 others (2015) Widespread excess ice in Arcadia Planitia, Mars. Geophysical Research Letters 42(16), 6566-6574. doi: 10.1002/2015GL064844.

Bruzzone $\mathbf{L}$ and 5 others (2011) Subsurface radar sounding of the Jovian moon Ganymede. Proceedings of the IEEE 99(5), 837-857. doi: 10.1109/ JPROC.2011.2108990.

Bruzzone L and 9 others (2013) RIME: radar for icy moon exploration. In 2013 IEEE International Geoscience and Remote Sensing SymposiumIGARSS. IEEE, Melbourne, Australia, pp. 3907-3910.

Buchardt SL and Dahl-Jensen D (2007) Estimating the basal melt rate at NorthGRIP using a Monte Carlo technique. Annals of Glaciology 45, 137-142. doi: 10.3189/172756407782282435.

Campbell BA, Schroeder DM and Whitten JL (2018) Mars radar clutter and surface roughness characteristics from MARSIS data. Icarus 299, 22-30. doi: 10.1016/j.icarus.2017.07.011.
Carrer L and Bruzzone L (2016) Automatic enhancement and detection of layering in radar sounder data based on a local scale hidden Markov model and the Viterbi algorithm. IEEE Transactions on Geoscience and Remote Sensing 55(2), 962-977. doi: 10.1109/TGRS.2016.2616949.

Carrer L and Bruzzone L (2017) Solving for ambiguities in radar geophysical exploration of planetary bodies by mimicking bats echolocation. Nature Communications 8(1), 1-12. doi: 10.1038/s41467-017-02334-1.

Carrer L, Gerekos C and Bruzzone L (2018) Distributed radar sounder system: a novel approach to across-track resolution enhancement and clutter reduction. In IGARSS 2018-2018 IEEE International Geoscience and Remote Sensing Symposium. IEEE, Valencia, Spain, pp. 6765-6768. doi: 10.1109/IGARSS.2018.8519462.

Carter SP and 5 others (2007) Radar-based subglacial lake classification in Antarctica. Geochemistry, Geophysics, Geosystems 8(3). doi: 10.1029/ 2006GC001408.

Carter SP, Fricker HA and Siegfried MR (2017) Antarctic subglacial lakes drain through sediment-floored canals: theory and model testing on real and idealized domains. The Cryosphere 11(1), 381. doi: 10.5194/tc-11-381-2017.

Castelletti D and 9 others (2017) An interferometric approach to cross-track clutter detection in two-channel VHF radar sounders. IEEE Transactions on Geoscience and Remote Sensing 55(11), 6128-6140. doi: 10.1109/TGRS. 2017.2721433.

Castelletti D and Schroeder D (2017) Estimating englacial vertical velocity from airborne radar sounding data. In AGU Fall Meeting Abstracts, San Francisco, CA.

Castelletti D, Schroeder DM, Mantelli E and Hilger A (2019) Layer optimized SAR processing and slope estimation in radar sounder data. Journal of Glaciology 65(254), 983-988. doi: 10.1017/jog.2019.72.

Catania GA, Conway H, Raymond CF and Scambos TA (2006) Evidence for floatation or near floatation in the mouth of Kamb Ice Stream, West Antarctica, prior to stagnation. Journal of Geophysical Research: Earth Surface 111, F01005. doi: 10.1029/2005JF000355.

Cavitte MGP and 7 others (2016) Deep radiostratigraphy of the East Antarctic plateau: connecting the Dome $\mathrm{C}$ and Vostok ice core sites. Journal of Glaciology 62(232), 323-334. doi: 10.1017/jog.2016.11.

Cavitte MG and 7 others (2018) Accumulation patterns around Dome C, East Antarctica, in the last $73 \mathrm{kyr}$. The Cryosphere 12(4), 1401-1414. doi: 10.5194/tc-12-1401-2018

Christian S, Holt J, Byrne S and Fishbaugh K (2013) Integrating radar stratigraphy with high resolution visible stratigraphy of the North Polar Layered Deposits, Mars. Icarus 226(2), 1241-1251. doi: https://doi.org/10.1016/j.icarus.2013.07.003.

Christianson K and 6 others (2016) Basal conditions at the grounding zone of Whillans Ice Stream, West Antarctica, from ice-penetrating radar. Journal of Geophysical Research: Earth Surface 121(11), 1954-1983. doi: 10.1002/ 2015JF003806.

Chu W and 5 others (2016) Extensive winter subglacial water storage beneath the Greenland ice sheet. Geophysical Research Letters 43(24), 12-484. doi: 10.1002/2016GL071538.

Chu W, Schroeder DM, Seroussi H, Creyts TT and Bell RE (2018b) Complex basal thermal transition near the onset of Petermann Glacier, Greenland. Journal of Geophysical Research: Earth Surface 123(5), 985-995. doi: 10.1029/2017JF004561.

Chu W, Schroeder D and Siegfried M (2018a) Retrieval of englacial firn aquifer thickness from ice-penetrating radar sounding in Southeastern Greenland. Geophysical Research Letters 45(21), 11770-11778. doi: 10.1029/2018GL079751.

Church G and 5 others (2019) Detecting and characterising an englacial conduit network within a temperate Swiss glacier using active seismic, ground penetrating radar and borehole analysis. Annals of Glaciology 60(79), 193-205. doi: 10.1017/aog.2019.19.

Conway H, Hall BL, Denton GH, Gades AM and Waddington ED (1999) Past and future grounding-line retreat of the West Antarctic ice sheet. Science (New York, N.Y.) 286(5438), 280-283. doi: 10.1126/science.286.5438.280.

Cooper MA and 5 others (2019) Subglacial roughness of the Greenland ice sheet: relationship with contemporary ice velocity and geology. The Cryosphere 13(11), 3093-3115. doi: 10.5194/tc-2019-73.

Corr HF, Jenkins A, Nicholls KW and Doake C (2002) Precise measurement of changes in ice-shelf thickness by phase-sensitive radar to determine basal melt rates. Geophysical Research Letters 29(8), 73. doi: 10.1029/2001GL014618.

Crandall DJ, Fox GC and Paden JD (2012) Layer-finding in radar echograms using probabilistic graphical models. In Proceedings of the 21st International 
Conference on Pattern Recognition (ICPR2012). IEEE, Sukuba Science City, Japan, pp. 1530-1533.

Culberg R and Schroeder DM (2019) Radar Scattering in Firn and its Implications for VHF/UHF Orbital Ice Sounding. In IGARSS 2019-2019 IEEE International Geoscience and Remote Sensing Symposium. IEEE, Yokohama, Japan, pp. 4137-4140. doi: 10.1109/IGARSS.2019.8898991.

Culha C, Schroeder DM, Jordan TM and Haynes MS (2020) Assessing the detectability of Europa's eutectic zone using radar sounding. Icarus 339, 113578. doi: 10.1016/j.icarus.2019.113578.

Dahl-Jensen D and 9 others (2013) Eemian interglacial reconstructed from a Greenland folded ice core. Nature 493(7433), 489-494. doi: 10.1038/nature11789.

Dall J and 9 others (2010) ESA's polarimetric airborne radar ice sounder (POLARIS): design and first results. IET Radar, Sonar \& Navigation 4(3), 488-496. doi: 10.1049/iet-rsn.2009.0035.

Dall J, Corr HF, Walker N, Rommen B and Lin CC (2018) Sounding the Antarctic ice sheet from space: a feasibility study based on airborne P-band radar data. In IGARSS 2018-2018 IEEE International Geoscience and Remote Sensing Symposium. IEEE, Valencia, Spain, pp. 4142-4145. doi: 10.1109/IGARSS.2018.8518826.

Davies D and 8 others (2018) How dynamic are ice-stream beds? The Cryosphere 12, 1615-1625. doi: 10.5194/tc-12-1615-2018.

Dean K, Naylor S, Turchetti S and Siegert M (2008) Data in Antarctic science and politics. Social Studies of Science 38(4), 571-604. doi: 10.1177/ 0306312708090693.

Delf R, Schroeder DM, Bingham RG and Giannopoulos A (2020) A comparison of automated approaches to extracting englacial-layer geometry across ice sheets. Annals of Glaciology 61(81), 234-241. doi: 10.1017/aog.2020.42.

Di Paolo F and 9 others (2016) Radar signal penetration and horizons detection on Europa through numerical simulations. IEEE Journal of Selected Topics in Applied Earth Observations and Remote Sensing 10(1), 118-129. doi: 10.1109/JSTARS.2016.2544103.

Doake C, Corr H and Jenkins A (2002) Polarization of radio waves transmitted through Antarctic ice shelves. Annals of Glaciology 34, 165-170. doi: 10. 3189/172756402781817572.

Donini E, Thakur S, Bovolo F and Bruzzone L (2019) An automatic approach to map refreezing ice in radar sounder data. In Image and Signal Processing for Remote Sensing XXV, Vol. 11155. International Society for Optics and Photonics, Strasbourg, France, p. 111551B. doi: 10.1117/12.2533169.

Dowdeswell J and 5 others (1986) Digital mapping of the Nordaustlandet ice caps from airborne geophysical investigations. Annals of Glaciology 8, 51-58. doi: 10.3189/S0260305500001130.

Dowdeswell J and 9 others (2002) Form and flow of the Academy of Sciences Ice Cap, Severnaya Zemlya, Russian High Arctic. Journal of Geophysical Research: Solid Earth 107(B4), 5-1-5-10. doi: 10.1029/2000JB000129.

Dowdeswell J, Benham T, Gorman M, Burgess D and Sharp M (2004) Form and flow of the Devon Island ice cap, Canadian Arctic. Journal of Geophysical Research: Earth Surface 109(F2), F02002. doi: 10.1029/2003JF000095.

Dowdeswell JA and Evans S (2004) Investigations of the form and flow of ice sheets and glaciers using radio-echo sounding. Reports on Progress in Physics 67(10), 1821-1861. doi: 10.1088/0034-4885/67/10/R03.

Drewry DJ (1983) Antarctica: Glaciological and Geophysical Folio, Vol. 2. UK: University of Cambridge, Scott Polar Research Institute Cambridge.

Drews R and 5 others (2012) Potential mechanisms for anisotropy in icepenetrating radar data. Journal of Glaciology 58(209), 613-624. doi: 10. 3189/2012JoG11J114.

Drews R and 5 others (2015) Evolution of Derwael ice rise in Dronning Maud Land, Antarctica, over the last millennia. Journal of Geophysical Research: Earth Surface 120(3), 564-579. doi: 10.1002/2014JF003246.

Drews R (2015) Evolution of ice-shelf channels in Antarctic ice shelves. The Cryosphere 9(3), 1169-1181. doi: 10.5194/tc-9-1169-2015.

Drews R and 9 others (2017) Actively evolving subglacial conduits and eskers initiate ice shelf channels at an Antarctic grounding line. Nature Communications 8(15228), 1-10. doi: 10.1038/ncomms15228.

Durand G, Gagliardini O, Favier L, Zwinger T and Le Meur E (2011) Impact of bedrock description on modeling ice sheet dynamics. Geophysical Research Letters 38(20). doi: 10.1029/2011GL048892.

Eisen $\mathbf{O}$ and 13 others (2008) Ground-based measurements of spatial and temporal variability of snow accumulation in East Antarctica. Reviews of Geophysics 46, RG2001-RG2008. doi: 10.1029/2006RG000218.

Eisen $\mathbf{O}$ (2008) Inference of velocity pattern from isochronous layers in firn, using an inverse method. Journal of Glaciology 54(187), 613-630. doi: 10. 3189/002214308786570818.
Eisen O, Hamann I, Kipfstuhl S, Steinhage D and Wilhelms F (2007) Direct evidence for continuous radar reflector originating from changes in crystalorientation fabric. The Cryosphere 1, 1-10. doi: 10.5194/tc-1-1-2007.

Eisen O, Winter A, Steinhage D, Kleiner T and Humbert A (2020) Basal roughness of the East Antarctic Ice Sheet in relation to flow speed and basal thermal state. Annals of Glaciology 61(81), 162-175. doi: 10.1017/ aog.2020.47.

Elsworth CW, Schroeder DM and Siegfried MR (2020) Interpreting englacial layer deformation in the presence of complex ice flow history with synthetic radargrams. Annals of Glaciology 61(81), 206-213. doi: 10. 1017/aog.2019.41.

Fahnestock M, Abdalati W, Joughin I, Brozena J and Gogineni P (2001) High geothermal heat flow, basal melt, and the origin of rapid ice flow in central Greenland. Science (New York, N.Y.) 294(5550), 2338-2342. doi: 10.1126/science.1065370.

Falcini FA, Rippin DM, Krabbendam M and Selby KA (2018) Quantifying bed roughness beneath contemporary and palaeo-ice streams. Journal of Glaciology 64(247), 822-834. doi: 10.1017/jog.2018.71.

Felix $\mathbf{N}$ and King EC (2011) Kinematic waves in polar firn stratigraphy. Journal of Glaciology 57(206), 1119-1134. doi: 10.3189/002214311798843340.

Ferro A (2019) Squinted SAR focusing for improving automatic radar sounder data analysis and enhancement. International Journal of Remote Sensing 40(12), 4762-4786. doi: 10.1080/01431161.2019.1573339.

Ferro A and Bruzzone L (2012) Automatic extraction and analysis of ice layering in radar sounder data. IEEE Transactions on Geoscience and Remote Sensing 51(3), 1622-1634. doi: 10.1109/TGRS.2012.2206078.

Fischer $\mathbf{H}$ and 5 others (2013) Where to find 1.5 million yr old ice for the IPICS Oldest-Ice ice core. Climate of the Past 9(6), 2489-2505. doi: 10. 5194/cp-9-2489-2013.

Forster RR and 9 others (2014) Extensive liquid meltwater storage in firn within the Greenland ice sheet. Nature Geoscience 7(2), 95-98. doi: 10 1038/ngeo2043.

Franke $S$ and 7 others (2020) Bed topography and subglacial landforms of the North East Greenland Ice Stream. Annals of Glaciology 61(81), 143-153. doi: $10.1017 /$ aog.2020.12.

Freeman A, Pi X and Heggy E (2017) Radar sounding through the Earth's ionosphere at $45 \mathrm{MHz}$. IEEE Transactions on Geoscience and Remote Sensing 55(10), 5833-5842. doi: 10.1109/TGRS.2017.2715838.

Fretwell P and 5 others (2013) Bedmap2: improved ice bed, surface and thickness datasets for Antarctica. The Cryosphere 7(1), 375-393. doi: 10.5194/tc-7-499-2013.

Fujita S, Matsuoka K, Maeno H and Furukawa T (2003) Scattering of VHF radio waves from within an ice sheet containing the vertical-girdle-type ice fabric and anisotropic reflection boundaries. Annals of Glaciology 37, 305-316. doi: 10.3189/172756403781815979.

Fürst JJ and 9 others (2018) The ice-free topography of Svalbard. Geophysical Research Letters 45(21), 11-760. doi: 10.1029/2018GL079734.

Gärtner-Roer I and 5 others (2014) A database of worldwide glacier thickness observations. Global and Planetary Change 122, 330-344. doi: 10.1016/ j.gloplacha.2014.09.003.

Gerekos C and 5 others (2018) A coherent multilayer simulator of radargrams acquired by radar sounder instruments. IEEE Transactions on Geoscience and Remote Sensing 56(12), 7388-7404. doi: 10.1109/TGRS.2018.2851020.

Gillet-Chaulet F, Hindmarsh RC, Corr HF, King EC and Jenkins A (2011) In situ quantification of ice rheology and direct measurement of the Raymond effect at Summit, Greenland using a phase-sensitive radar. Geophysical Research Letters 38(24), L24503. doi: 10.1029/2011GL049843.

Gladish CV, Holland DM, Holland PR and Price SF (2012) Ice-shelf basal channels in a coupled ice/ocean model. Journal of Glaciology 58(212), 1227-1244. doi: 10.3189/2012JoG12J003.

Glassmeier KH, Boehnhardt H, Koschny D, Kührt E and Richter I (2007) The Rosetta mission: flying towards the origin of the solar system. Space Science Reviews 128(1-4), 1-21. doi: 10.1007/s11214-006-9140-8.

Glen J and Paren J (1975) The electrical properties of snow and ice. Journal of Glaciology 15(73), 15-38. doi: 10.3189/\$0022143000034249.

Goff JA, Powell EM, Young DA and Blankenship DD (2014) Instruments and methods conditional simulation of Thwaites Glacier (Antarctica) bed topography for flow models: incorporating inhomogeneous statistics and channelized morphology. Journal of Glaciology 60(22), 635-646. doi: 10.3189/2014JoG13J200.

Gogineni SP and 9 others (2001) Coherent radar ice thickness measurements over the Greenland ice sheet. Journal of Geophysical Research: Atmospheres 106(D24), 33761-33772. doi: 10.1029/2001JD900183. 
Gogineni SP and 9 others (2014) Bed topography of Jakobshavn Isbræ, Greenland, and Byrd Glacier, Antarctica. Journal of Glaciology 60(233), 813-833. doi: 10.3189/2014JoG14J129.

Gogineni SP and 6 others (2018) A CubeSat train for radar sounding and imaging of Antarctic ice sheet. In IGARSS 2018-2018 IEEE International Geoscience and Remote Sensing Symposium. IEEE, Valencia, Spain, pp. 4138-4141. doi: 10.1109/IGARSS.2018.8519162.

Gogineni S, Chuah T, Allen C, Jezek K and Moore RK (1998) An improved coherent radar sounder. Journal of Glaciology 44(148), 659-669. doi: $10.3189 / \mathrm{S} 0022143000002161$

Goldberg ML and 5 others (2020) Automated detection and characterization of Antarctic basal units using radar sounding data: demonstration in Institute Ice Stream, West Antarctica. Annals of Glaciology 61(81), 242248. doi: 10.1017/aog.2020.27.

Gorman MR and Siegert MJ (1999) Penetration of Antarctic subglacial lakes by vhf electromagnetic pulses: information on the depth and electrical conductivity of basal water bodies. Journal of Geophysical Research: Solid Earth 104(B12), 29311-29320. doi: 10.1029/1999JB900271.

Gourmelen N and 9 others (2017) Channelized melting drives thinning under a rapidly melting Antarctic ice shelf. Geophysical Research Letters 44(19), 9796-9804. doi: 10.1002/2017GL074929.

Greenbaum J and 9 others (2015) Ocean access to a cavity beneath Totten Glacier in East Antarctica. Nature Geoscience 8(4), 294-298. doi: 10.1038/ngeo2388.

Grima C and 7 others (2009) North polar deposits of Mars: extreme purity of the water ice. Geophysical Research Letters 36(3), L03203. doi:10.1029/ 2008GL036326.

Grima C and 6 others (2016) Radar detection of the brine extent at McMurdo Ice Shelf, Antarctica, and its control by snow accumulation. Geophysical Research Letters 43(13), 7011-7018. doi: 10.1002/2016GL069524.

Grima C, Blankenship DD and Schroeder DM (2015) Radar signal propagation through the ionosphere of Europa. Planetary and Space Science 117, 421-428. doi:10.1016/j.pss.2015.08.017.

Grima C, Blankenship DD, Young DA and Schroeder DM (2014a) Surface slope control on firn density at Thwaites Glacier, West Antarctica: results from airborne radar sounding. Geophysical Research Letters 41(19), 6787-6794. doi: 10.1002/2014GL061635.

Grima C, Schroeder DM, Blankenship DD and Young DA (2014b) Planetary landing-zone reconnaissance using ice-penetrating radar data: concept validation in Antarctica. Planetary and Space Science 103, 191-204. doi: 10.1016/j.pss.2014.07.018.

Guallini L and 7 others (2018) Regional stratigraphy of the south polar layered deposits (Promethei Lingula, Mars): discontinuity-bounded units in images and radargrams. Icarus 308, 76-107. doi: https://doi.org/10. 1016/j.icarus.2017.08.030, mars Polar Science VI.

Gudlaugsson E, Humbert A, Winsborrow M and Andreassen K (2013) Subglacial roughness of the former Barents Sea ice sheet. Journal of Geophysical Research: Earth Surface 118(4), 2546-2556. doi: 10.1002/2013JF002714.

Gudmandsen P (1969) Airborne radio echo sounding of the Greenland ice sheet. The Geographical Journal 135(4), 548-551. doi: 10.2307/1795099.

Gudmandsen P (1975) Layer echoes in polar ice sheets. Journal of Glaciology 15(73), 95-101. doi: 10.3189/S0022143000034304.

Gudmundsson GH (2011) Inverse methods in glaciology. In Singh VP, Singh P and Haritashya UK (eds), Encyclopedia of Snow, Ice and Glaciers. Springer, pp. 653-656.

Hamran SE and Aarholt E (1993) Glacier study using wavenumber domain synthetic aperture radar. Radio Science 28(04), 559-570. doi: 10.1029/92RS03022.

Harrison CH (1973) Radio echo sounding of horizontal layers in ice. Journal of Glaciology 12(66), 383-397. doi: 10.3189/S0022143000031804.

Hascoët L and Morlighem M (2018) Source-to-source adjoint algorithmic differentiation of an ice sheet model written in C. Optimization Methods and Software 33(4-6), 829-843. doi: 10.1080/10556788.2017.1396600.

Haynes M (2020) Surface and subsurface radar equations for radar sounders. Annals of Glaciology 61(81), 135-142. doi: 10.1017/aog.2020.16.

Haynes MS, Chapin E, Moussessian A and Madsen SN (2018a) Surface clutter discrimination analysis for radar sounding interferometry. IEEE Transactions on Aerospace and Electronic Systems 55(2), 989-1003. doi: 10.1109/TAES.2018.2867689.

Haynes MS, Chapin E and Schroeder DM (2018b) Geometric power fall-off in radar sounding. IEEE Transactions on Geoscience and Remote Sensing 56(11), 6571-6585. doi: 10.1109/TGRS.2018.2840511.

Heggy E, Scabbia G, Bruzzone L and Pappalardo RT (2017) Radar probing of Jovian icy moons: understanding subsurface water and structure detectability in the JUICE and Europa missions. Icarus 285, 237-251. doi: 10.1016/j.icarus.2016.11.039.

Heister A and Scheiber R (2018) Coherent large beamwidth processing of radio-echo sounding data. Cryosphere 12(9), 2969-2979. doi: 10.5194/ tc-12-2969-2018.

Hélière F, Lin CC, Corr H and Vaughan D (2007) Radio echo sounding of Pine Island Glacier, West Antarctica: aperture synthesis processing and analysis of feasibility from space. IEEE Transactions on Geoscience and Remote Sensing 45(8), 2573-2582. doi: 10.1109/TGRS.2007.897433.

Hempel L, Thyssen F, Gundestrup N, Clausen HB and Miller H (2000) A comparison of radio-echo sounding data and electrical conductivity of the GRIP ice core. Journal of Glaciology 46(154), 369-374. doi: 10.3189/ 172756500781833070.

Hills BH, Christianson K and Holshuh N (2020) A framework for attenuation method selection evaluated with ice-penetrating radar data at south pole lake. Annals of Glaciology 61(81), 176-187. doi: 10.1017/aog.2020.32.

Hindmarsh RC and 5 others (2011) Flow at ice-divide triple junctions: 2. three-dimensional views of isochrone architecture from ice-penetrating radar surveys. Journal of Geophysical Research: Earth Surface 116(F2), F02024. doi: 10.1029/2009JF001611.

Hindmarsh RCA, Leysinger Vieli GJMC and Parrenin F (2009) A large-scale numerical model for computing isochrone geometry. Annals of Glaciology 50(51), 130-140. doi: 10.3189/172756409789097450.

Hindmarsh RCA, Leysinger Vieli GJMC, Raymond MJ and Gudmundsson GH (2006) Draping or overriding: the effect of horizontal stress gradients on internal layer architecture in ice sheets. Journal of Geophysical Research: Earth Surface 111(F02018). doi: 10.1029/2005JF000309.

Holschuh N, Christianson K, Anandakrishnan S, Alley RB and Jacobel RW (2016) Constraining attenuation uncertainty in common midpoint radar surveys of ice sheets. Journal of Geophysical Research: Earth Surface 121(10), 1876-1890. doi: 10.1002/2016JF003942.

Holschuh N, Christianson K, Paden J, Alley R and Anandakrishnan S (2020) Linking postglacial landscapes to glacier dynamics using swath radar at Thwaites Glacier, Antarctica. Geology 48. doi: 10.1130/G46772.1.

Holschuh N, Lilien D and Christianson K (2019) Thermal weakening, convergent flow, and vertical heat transport in the Northeast Greenland Ice Stream shear margins. Geophysical Research Letters 46, 8184-8193. doi: 10.1029/2019GL083436.

Holschuh N, Parizek BR, Alley RB and Anandakrishnan S (2017) Decoding ice sheet behavior using englacial layer slopes. Geophysical Research Letters 44(11), 5561-5570. doi: 10.1002/2017GL073417.

Holt JW and 8 others (2006) New boundary conditions for the West Antarctic ice sheet: subglacial topography of the Thwaites and Smith Glacier catchments. Geophysical Research Letters 33(9), GL025561. doi: 10.1029/ 2005GL025561.

Humbert A, Steinhage D, Helm V, Beyer S and Kleiner T (2018) Missing evidence of widespread subglacial lakes at Recovery Glacier, Antarctica. Journal of Geophysical Research: Earth Surface 123(11), 2802-2826. doi: 10.1029/2017JF004591.

Ilisei AM and Bruzzone L (2015) A system for the automatic classification of ice sheet subsurface targets in radar sounder data. IEEE Transactions on Geoscience and Remote Sensing 53(6), 3260-3277. doi: 10.1109/TGRS.2014.2372818.

Ilisei AM, Khodadadzadeh M, Ferro A and Bruzzone L (2018) An automatic method for subglacial lake detection in ice sheet radar sounder data. IEEE Transactions on Geoscience and Remote Sensing 57(6), 3252-3270. doi: 10. 1109/TGRS.2018.2882911.

Jacobel RW and Hodge SM (1995) Radar internal layers from the Greenland summit. Geophysical Research Letters 22(5), 587-590. doi: 10.1029/95GL00110.

Jacobel RW, Welch BC, Osterhouse D, Pettersson R and MacGregor JA (2009) Spatial variation of radar-derived basal conditions on Kamb Ice Stream, West Antarctica. Annals of Glaciology 50(51), 10-16. doi: 10. 3189/172756409789097504

Jenkins A (2011) Convection-driven melting near the grounding lines of ice shelves and tidewater glaciers. Journal of Physical Oceanography 41(12), 2279-2294. doi: 10.1175/JPO-D-11-03.1.

Jeofry $\mathbf{H}$ and 8 others (2018) Hard rock landforms generate $130 \mathrm{~km}$ ice shelf channels through water focusing in basal corrugations. Nature Communications 9(1), 4576. doi: 10.1038/s41467-018-06679-z.

Jeofry H, Ross N and Siegert MJ (2019) Comparing numerical ice-sheet model output with radio-echo sounding measurements in the Weddell Sea sector of West Antarctica. Annals of Glaciology 61(81), 188-197. doi: 10.1017/aog.2019.39. 
Jezek K and 7 others (2006) Glaciers and ice sheets mapping orbiter concept. Journal of Geophysical Research: Planets 111(E6), E06S20. doi: 10.1029/ 2005JE002572.

Johari GP and Charette P (1975) The permittivity and attenuation in polycrystalline and single-crystal ice Ih at 35 and $60 \mathrm{MHz}$. Journal of Glaciology 14(71), 293-303. doi: 10.3189/S002214300002178.

Jordan R and 18 others (2009) The Mars express MARSIS sounder instrument. Planetary and Space Science 57, 1975-1986. doi: 10.1016/j.pss.2009.09.016.

Jordan TM and 7 others (2016) An ice-sheet-wide framework for englacial attenuation from ice-penetrating radar data. The Cryosphere 10(4), 15471570. doi: 10.5194/tc-10-1547-2016.

Jordan TM and 6 others (2017) Self-affine subglacial roughness: consequences for radar scattering and basal water discrimination in northern Greenland. The Cryosphere 11(3), 1247-1264. doi: 10.5194/tc-11-1247-2017.

Jordan TA and 7 others (2018a) Anomalously high geothermal flux near the south pole. Scientific Reports 8(1), 16785. doi: 10.1038/s41598-018-35182-0.

Jordan TM and 8 others (2018b) A constraint upon the basal water distribution and thermal state of the Greenland ice sheet from radar bed echoes. The Cryosphere 12(9), 2831-2854. doi: 10.5194/tc-12-2831-2018.

Jordan TM, Schroeder DM, Castelletti D, Li J and Dall J (2019) A polarimetric coherence method to determine ice crystal orientation fabric from radar sounding: application to the NEEM Ice Core Region. IEEE Transactions on Geoscience and Remote Sensing 57(11), 8641-8657. doi: 10.1109/TGRS. 2019.2921980.

Jordan TM, Schroeder DM, Elsworth CW and Siegfried MR (2020a) Estimation of ice fabric within Whillans Ice Stream using polarimetric phase-sensitive radar sounding. Annals of Glaciology 61(81), 74-83. doi: 10.1017/aog.2020.6.

Jordan TM and 6 others (2020b) Modeling ice birefringence and oblique radio wave propagation for neutrino detection at the South Pole. Annals of Glaciology 61(81), 84-91. doi: 10.1017/aog.2020.18.

Kalousová K, Schroeder DM and Soderlund KM (2017) Radar attenuation in Europa's ice shell: obstacles and opportunities for constraining the shell thickness and its thermal structure. Journal of Geophysical Research: Planets 122(3), 524-545. doi: 10.1002/2016JE005110.

Karlsson NB and 9 others (2016) Accumulation rates during 1311-2011 CE in North-Central Greenland derived from air-borne radar data. Frontiers in Earth Science 4, 97. doi: 10.3389/feart.2016.00097.

Karlsson NB and 6 others (2018) Glaciological characteristics in the dome Fuji region and new assessment for 'oldest ice'. The Cryosphere 12(7), 2413-2424. doi: 10.5194/tc-12-2413-2018.

Karlsson NB and 6 others (2020) Surface accumulation in Northern Central Greenland during the last 300 years. Annals of Glaciology 61(81), 214-224. doi: 10.1017/aog.2020.30.

Karlsson NB, Schmidt LS and Hvidberg CS (2015) Volume of Martian midlatitude glaciers from radar observations and ice flow modeling. Geophysical Research Letters 42(8), 2627-2633. doi: 10.1002/2015GL063219.

Kendrick A and 9 others (2018) Surface meltwater impounded by seasonal englacial storage in West Greenland. Geophysical Research Letters 45(19), 10474-10481. doi: 10.1029/2018GL079787.

Khazendar A and 8 others (2016) Rapid submarine ice melting in the grounding zones of ice shelves in West Antarctica. Nature Communications 7, 1-8. doi: 10.1038/ncomms 13243 .

King EC (2020) The precision of radar-derived subglacial bed topography, a case study from Pine Island Glacier, Antarctica. Annals of Glaciology 61 (81), 154-161. doi: 10.1017/aog.2020.33.

King EC, Pritchard HD and Smith AM (2016) Subglacial landforms beneath Rutford Ice Stream, Antarctica: detailed bed topography from ice-penetrating radar. Earth System Science Data 8(1), 151-158. doi: 10.5194/essd-8-151-2016.

Kingslake J and 9 others (2014) Full-depth englacial vertical ice sheet velocities measured using phase-sensitive radar. Journal of Geophysical Research: Earth Surface 119(12), 2604-2618. doi: 10.1002/2014JF003275.

Kingslake J, Martín C, Arthern RJ, Corr HFJ and King EC (2016) Ice-flow reorganization in West Antarctica $2.5 \mathrm{kyr}$ ago dated using radar-derived englacial flow velocities. Geophysical Research Letters 43(17), 9103-9112. doi: 10.1002/2016GL070278

Kjær KH and 9 others (2018) A large impact crater beneath Hiawatha Glacier in northwest Greenland. Science Advances 4(11), eaar8173. doi: 10.1126/ sciadv.aar8173.

Koenig LS and 12 others (2016) Annual Greenland accumulation rates (20092012) from airborne snow radar. The Cryosphere 10(4), 1739-1752. doi: 10. 5194/tc-10-1739-2016.
Kofman W and 9 others (2015) Properties of the 67P/ChuryumovGerasimenko interior revealed by CONSERT radar. Science (New York, N.Y.) 349(6247), aab0639. doi: 10.1126/science.aab0639.

Kofman W, Orosei R and Pettinelli E (2010) Radar signal propagation and detection through ice. Space Science Reviews 153(1-4), 249-271. doi: 10. 1007/s11214-010-9642-.

Koh G, Lever JH, Arcone SA, Marshall HP and Ray LE (2010) Autonomous FMCW radar survey of Antarctic shear zone. In Proceedings of the XIII International Conference on Ground Penetrating Radar. IEEE, Lecce, Italy, pp. 1-5. doi: 10.1109/ICGPR.2010.5550174.

Koutnik MR and 7 others (2016) Holocene accumulation and ice flow near the West Antarctic ice sheet divide ice core site. Journal of Geophysical Research: Earth Surface 121, 907-924. doi: 10.1002/ 2015JF003668.

Koutnik MR and Waddington ED (2012) Well-posed boundary conditions for limited-domain models of transient ice flow near an ice divide. Journal of Glaciology 58(211), 1008-1020. doi: 10.3189/ 2012JoG11J212.

Kyrke-Smith TM, Gudmundsson GH and Farrell PE (2018) Relevance of detail in basal topography for basal slipperiness inversions: a case study on Pine Island Glacier, Antarctica. Frontiers in Earth Science 6, 33. doi: 10.3389/feart.2018.00033.

Lalich DE and Holt JW (2017) New Martian climate constraints from radar reflectivity within the North Polar Layered Deposits. Geophysical Research Letters 44(2), 657-664. doi: 10.1002/2016GL071323.

Lalich DE, Holt JW and Smith IB (2019) Radar reflectivity as a proxy for the dust content of individual layers in the Martian North Polar Layered Deposits. Journal of Geophysical Research: Planets 124(7), 1690-1703. doi: 10.1029/2018JE005787.

Langhammer L, Grab M, Bauder A and Maurer H (2019) Glacier thickness estimations of alpine glaciers using data and modeling constraints. The Cryosphere 2019, 1-26. doi: 10.5194/tc-2019-55.

Le Brocq AM and 9 others (2013) Evidence from ice shelves for channelized meltwater flow beneath the Antarctic ice sheet. Nature Geoscience 6(11), 945-948. doi: 10.1038/ngeo1977.

Legarsky JJ, Gogineni SP and Akins TL (2001) Focused synthetic aperture radar processing of ice-sounder data collected over the Greenland ice sheet. IEEE Transactions on Geoscience and Remote Sensing 39(10), 2109-2117. doi: 10.1109/36.957274.

Leuschen C, Gogineni S and Tammana D (2000) SAR processing of radar echo sounder data. In IGARSS 2000. IEEE 2000 International Geoscience and Remote Sensing Symposium. Taking the Pulse of the Planet: The Role of Remote Sensing in Managing the Environment. Proceedings (Cat. No. 00CH37120), Vol. 6. IEEE, Honolulu Hawaii, pp. 2570-2572. doi: 10. 1109/IGARSS.2000.859643.

Lewis G and 5 others (2017) Regional Greenland accumulation variability from Operation IceBridge airborne accumulation radar. The Cryosphere 11(2), 773-788. doi: 10.5194/tc-11-773-2017.

Leysinger-Vieli G, Hindmarsh R and Siegert M (2007) Three-dimensional flow influences on radar layer stratigraphy. Annals of Glaciology 46(1), 22-28. doi: 10.3189/172756407782871729.

Leysinger Vieli GJMC, Martín C and Hindmarsh RCA (2018) Basal freezeon generates complex ice-sheet stratigraphy. Nature Communications 9(1), 4669. doi: 10.1038/s41467-018-07083-3.

Li J and 8 others (2018) Multi-channel and multi-polarization radar measurements around the NEEM site. The Cryosphere 12(8), 2689-2705. doi: 10. 5194/tc-12-2689-2018.

Lilien DA, Hills B, Driscol J, Jacobel R and Christianson K (2020) ImpDAR: an open-source impulse radar processor. Annals of Glaciology 61(81), 114123. doi: $10.1017 /$ aog.2020.44.

Lorente $\mathbf{R}$ and 7 others (2017) The ESA JUICE mission: the Science and the Science Operations. In EGU General Assembly Conference Abstracts, Vol. 19, Vienna, Austria, p. 14611.

Lythe MB and Vaughan DG (2001) BEDMAP: a new ice thickness and subglacial topographic model of Antarctica. Journal of Geophysical Research: Solid Earth 106(B6), 11335-11351. doi: 10.1029/2000JB900449.

MacGregor JA and 9 others (2015a) Radiostratigraphy and age structure of the Greenland ice sheet. Journal of Geophysical Research: Earth Surface 120, 1-30. doi: 10.1002/2014JF003215.

MacGregor JA and 9 others (2015b) Radar attenuation and temperature within the Greenland ice sheet. Journal of Geophysical Research: Earth Surface 120(6), 983-1008. doi: 10.1002/2014JF003418. 
MacGregor JA and 6 others (2016) Holocene deceleration of the Greenland ice sheet. Science (New York, N.Y.) 351(6273), 590-593. doi: 10.1126/science.aab1702.

MacKie EJ and Schroeder DM (2019) Paleo Observations Used to Geostatistically Simulate the Subglacial Geology of Thwaites Glacier. AGU Fall Meeting, August 2019, San Francisco.

Martín C, Gudmundsson GH, Pritchard HD and Gagliardini O (2009) On the effects of anisotropic rheology on ice flow, internal structure, and the age-depth relationship at ice divides. Journal of Geophysical Research: Earth Surface 114(F4), F04001. doi: 10.1029/2008JF001204.

Masolov VN, Popov SV, Lukin VV, Sheremetyev AN and Popkov AM (2006) Russian geophysical studies of Lake Vostok, Central East Antarctica. In Antarctica. Springer, Berlin, Heidelberg, pp. 135-140. doi: 10.1007/3-540-32934-X-16.

Matsuoka K and 6 others (2003) Crystal orientation fabrics within the Antarctic ice sheet revealed by a multipolarization plane and dual-frequency radar survey. Journal of Geophysical Research: Solid Earth 108(B10), 1-10. doi: 10.1029/2003JB002425.

Matsuoka K (2011) Pitfalls in radar diagnosis of ice-sheet bed conditions: lessons from englacial attenuation models. Geophysical Research Letters 38(5), L05505. doi: 10.1029/2010GL046205.

Matsuoka K, MacGregor JA and Pattyn F (2012) Predicting radar attenuation within the Antarctic ice sheet. Earth and Planetary Science Letters 359, 173183. doi: 10.1016/j.epsl.2012.10.018.

Matsuoka K, Morse D and Raymond C (2010) Estimating englacial radar attenuation using depth profiles of the returned power, central West Antarctica. Journal of Geophysical Research: Earth Surface 115(F2), F02012. doi: 10.1029/2009JF001496.

McKinnon W (2005) Radar sounding of convecting ice shells in the presence of convection: application to Europa, Ganymede, and Callisto. In Workshop on Radar Investigations of Planetary and Terrestrial Environments, Houston, TX.

Medley B and 5 others (2014) Constraining the recent mass balance of Pine Island and Thwaites glaciers, West Antarctica, with airborne observations of snow accumulation. The Cryosphere 8(4), 1375-1392. doi: 10.5194/tc-8-1375-2014.

Michaelides RJ and Schroeder DM (2019) Doppler-based discrimination of radar sounder target scattering properties: a case study of subsurface water geometry in Europa's ice shell. Icarus 326, 29-36. doi: 10.1016/j.icarus.2019.02.037.

Mingo L, Flowers GE, Crawford AJ, Mueller DR and Bigelow DG (2020) A stationary impulse-radar system for autonomous deployment in cold and temperate environments. Annals of Glaciology 61(81), 99-107. doi: 10. 1017/aog.2020.2.

Mirino M, Frigeri A, Orosei R, Rossi AP and Cantini F (2018) MARSIS radar data interpretation to characterize the deeper layers in the North Polar Cap on Mars. Advances in Astronautics Science and Technology 1(1), 31-37. doi: 10.1007/s42423-018-0008-2.

Montgomery L, Koenig L, Lenaerts JTM and Kuipers Munneke P (2020) Accumulation rates (2009-2017) in Southeast Greenland derived from airborne snow radar and comparison with regional climate models. Annals of Glaciology 61(81), 225-233. doi: doi:10.1017/aog.2020.8.

Moore JC (2000) Models of radar absorption in Europan ice. Icarus 147(1), 292-300. doi: 10.1006/icar.2000.6425.

Moore JC and Fujita S (1993) Dielectric properties of ice containing acid and salt impurity at microwave and low frequencies. Journal of Geophysical Research: Solid Earth 98(B6), 9769-9780. doi: 10.1029/93JB00710.

Morlighem M and 5 others (2011) A mass conservation approach for mapping glacier ice thickness. Geophysical Research Letters 38, L19503. doi: 10.1029/2011GL048659.

Morlighem M and 5 others (2017) BedMachine v3: complete bed topography and ocean bathymetry mapping of Greenland from multibeam echo sounding combined with mass conservation. Geophysical Research Letters 44(21), 11-051. doi: 10.1002/2017GL074954.

Morlighem M and 9 others (2019) Deep glacial troughs and stabilizing ridges unveiled beneath the margins of the Antarctic ice sheet. Nature Geoscience 13, 132-137. doi: 10.1038/s41561-019-0510-8.

Musil GJ and Doake C (1987) Imaging subglacial topography by a synthetic aperture radar technique. Annals of Glaciology 9, 170-175. doi: 10.3189/ S0260305500000562.

Muto A, Alley RB, Parizek BR and Anandakrishnan S (2019) Bed-type variability and till (dis)continuity beneath Thwaites Glacier, West Antarctica. Annals of Glaciology 1-9. doi: 10.1017/aog.2019.32.

Nereson N and Raymond C (2001) The elevation history of ice streams and the spatial accumulation pattern along the Siple Coast of West Antarctica inferred from ground-based radar data from three inter-ice-stream ridges. Journal of Glaciology 47(157), 303-313. doi: 10.3189/172756501781832197.

Nereson NA and Waddington ED (2002) Isochrones and isotherms beneath migrating ice divides. Journal of Glaciology 48(160), 95-108. doi: 10.3189/ 172756502781831647.

Nerozzi S and Holt JW (2018) Earliest accumulation history of the North Polar Layered Deposits, Mars from SHARAD. Icarus 308, 128-137. doi: 10.1016/j.icarus.2017.05.027.

Nerozzi S and Holt JW (2019) Buried ice and sand caps at the North Pole of Mars: revealing a record of climate change in the Cavi Unit with SHARAD. Geophysical Research Letters 46(13), 7278-7286. doi: 10.1029/ 2019GL082114.

Ng F and Conway H (2004) Fast-flow signature in the stagnated Kamb Ice Stream, West Antarctica. Geology 32(6), 481-484. doi: 10.1130/G20317.1.

Nicholls KW and 5 others (2015) A ground-based radar for measuring vertical strain rates and time-varying basal melt rates in ice sheets and shelves. Journal of Glaciology 61(230), 1079-1087. doi: 10.3189/2015JoG15J073.

Nielsen LT, Karlsson NB and Hvidberg CS (2015) Large-scale reconstruction of accumulation rates in northern Greenland from radar data. Annals of Glaciology 56(70), 70-78. doi: 10.3189/2015AoG70A062.

Nozette S and 10 others (2010) The lunar Reconnaissance Orbiter miniature radio frequency (Mini-RF) technology demonstration. Space Science Reviews 150, 285-302. doi: 10.1007/s11214-009-9607-5.

Onana V, Koenig LS, Ruth J, Studinger M and Harbeck JP (2015) A semiautomated multilayer picking algorithm for ice-sheet radar echograms applied to ground-based near-surface data. IEEE Transactions on Geoscience and Remote Sensing 53(1), 51-69. doi: 10.1109/TGRS.2014. 2318208.

Orosei R and 21 others (2018) Radar evidence of subglacial liquid water on Mars. Science (New York, N.Y.) 361(6401), 490-493. doi: 10.1126/science. aar7268.

Oswald G and Gogineni SP (2008) Recovery of subglacial water extent from Greenland radar survey data. Journal of Glaciology 54(184), 94-106. doi: 10. 3189/002214308784409107.

Oswald GK, Rezvanbehbahani S and Stearns LA (2018) Radar evidence of ponded subglacial water in Greenland. Journal of Glaciology 64(247), 711-729. doi: 10.1017/jog.2018.60.

Oswald G and Robin GdQ (1973) Lakes beneath the Antarctic ice sheet. Nature 245(5423), 251-254. doi: 10.1038/245251a0.

Paden JD and 5 others (2005) Wideband measurements of ice sheet attenuation and basal scattering. IEEE Geoscience and Remote Sensing Letters 2(2), 164-168. doi: 10.1109/LGRS.2004.842474.

Paden JD, Akins T, Dunson D, Allen C and Gogineni P (2010) Ice-sheet bed 3-D tomography. Journal of Glaciology 56(195), 3-11. doi: 10.3189/ 002214310791190811.

Palmer SJ and 8 others (2013) Greenland subglacial lakes detected by radar. Geophysical Research Letters 40(23), 6154-6159. doi: 10.1002/2013GL058383.

Panton C and Karlsson NB (2015) Automated mapping of near bed radioecho layer disruptions in the Greenland ice sheet. Earth and Planetary Science Letters 432, 323-331. doi: 10.1016/j.epsl.2015.10.024.

Pappalardo $\mathbf{R}$ and 7 others (2015) Science and reconnaissance from the Europa clipper mission concept: exploring Europa's habitability. In EGU General Assembly Conference Abstracts, Vol. 17, Vienna, Austria.

Paren JG and Robin G (1975) Internal reflections in polar ice sheets. Journal of Glaciology 14, 251-259. doi: 10.3189/S0022143000021730.

Parrenin F and 11 others (2017) Is there 1.5-million-year-old ice near Dome C, Antarctica? The Cryosphere 11(6), 2427-2437. doi: 10.5194/ tc-11-2427-2017

Parrenin F, Hindmarsh R and Rémy F (2006) Analytical solutions for the effect of topography, accumulation rate and lateral flow divergence on isochrone layer geometry. Journal of Glaciology 52(177), 191-202. doi: 10. 3189/172756506781828728.

Parsons R and Holt J (2016) Constraints on the formation and properties of a Martian Lobate debris apron: Insights from high-resolution topography, SHARAD radar data, and a numerical ice flow model. Journal of Geophysical Research: Planets 121(3), 2015JE004927. doi: 10.1002/2015JE004927.

Patterson GW and 9 others (2017) Bistatic radar observations of the Moon using Mini-RF on LRO and the Arecibo Observatory. Icarus 283, 2-19. doi: 10.1016/j.icarus.2016.05.017.

Paxman GJ and 5 others (2019) Subglacial geology and geomorphology of the Pensacola-Pole Basin, East Antarctica. Geochemistry, Geophysics, Geosystems 20, 2786-2807. doi: 10.1029/2018GC008126. 
Peters ME and 5 others (2007) Along-track focusing of airborne radar sounding data from West Antarctica for improving basal reflection analysis and layer detection. IEEE Transactions on Geoscience and Remote Sensing 45(9), 2725-2736. doi: 10.1109/TGRS.2007.897416.

Peters ME, Blankenship DD and Morse DL (2005) Analysis techniques for coherent airborne radar sounding: application to West Antarctic ice streams. Journal of Geophysical Research: Solid Earth 110(B6), B06303. doi: 10.1029/2004JB003222.

Peters ST, Schroeder DM, Castelletti D, Haynes M and Romero-Wolf A (2018) In situ demonstration of a passive radio sounding approach using the sun for echo detection. IEEE Transactions on Geoscience and Remote Sensing 56(12), 7338-7349. doi: 10.1109/TGRS.2018.2850662.

Petersen EI, Holt JW and Levy JS (2018) High ice purity of Martian Lobate Debris Aprons at the regional scale: evidence from an orbital radar sounding survey in Deuteronilus and Protonilus Mensae. Geophysical Research Letters 45(21), 11595-11604. doi: 10.1029/2018GL079759.

Pettinelli E and 6 others (2015) Dielectric properties of Jovian satellite ice analogs for subsurface radar exploration: a review. Reviews of Geophysics 53(3), 593-641. doi: 10.1002/2014RG000463.

Pettit EC and 6 others (2011) The crossover stress, anisotropy and the ice flow law at Siple Dome, West Antarctica. Journal of Glaciology 57(201), 39-52. doi: $10.3189 / 002214311795306619$.

Popov S (2017) Flow-lines computation and their use in subglacial geomorphology and glacial erosion modeling: the Princess Elizabeth land (East Antarctica) case study. Geomorfologiya 2017(1), 46-54. doi: 10.15356/ 0435-4281-2017-1-46-54.

Popov S (2020) Fifty-five years of Russian radio-echo sounding investigations in Antarctica. Annals of Glaciology 61(81), 14-24. doi: 10.1017/aog.2020.4.

Pritchard HD (2014) Bedgap: where next for Antarctic subglacial mapping? Antarctic Science 26(6), 742-757. doi: 10.1017/S095410201400025X.

Pritchard HD, King EC, McCarthy M and Mayer C (2020) Bedmap Himalayas: development of an airborne ice-sounding radar for glacier thickness surveys in High-Mountain Asia. Annals of Glaciology 61(81), 35-35. doi: $10.1017 /$ aog.2020.29.

Putzig NE and 6 others (2018) Three-dimensional radar imaging of structures and craters in the Martian polar caps. Icarus 308, 138-147. doi: 10.1016/j. icarus.2017.09.023.

Rahnemoonfar M, Fox GC, Yari M and Paden J (2017) Automatic ice surface and bottom boundaries estimation in radar imagery based on level-set approach. IEEE Transactions on Geoscience and Remote Sensing 55(9), 5115-5122. doi: 10.1109/TGRS.2017.2702200.

Rasmussen L (1988) Bed topography and mass-balance distribution of Columbia Glacier, Alaska, USA, determined from 1048 sequential aerial photography. Journal of Glaciology 34(117), 208-216. doi: 10.3189/ S0022143000032251.

Raymond CF (1983) Deformation in the vicinity of ice divides. Journal of Glaciology 29(103), 357-373. doi: 10.3189/S0022143000030288.

Rezvanbehbahani S, Stearns LA, Kadivar A, Walker JD and van der Veen CJ, 2017) Predicting the geothermal heat flux in Greenland: a machine learning approach. Geophysical Research Letters 44(24), 12-271. doi: 10.1002/2017GL075661.

Rezvanbehbahani S, Stearns LA, van der Veen CJ, Oswald GKA and Greve R (2019) Constraining the geothermal heat flux in Greenland at regions of radar-detected basal water. Journal of Glaciology 65(254), 1023-1034. doi: 10.1017/jog.2019.79.

Rignot E, Mouginot J, Larsen C, Gim Y and Kirchner D (2013) Low-frequency radar sounding of temperate ice masses in Southern Alaska. Geophysical Research Letters 40(20), 5399-5405. doi: 10.1002/2013GL057452.

Rippin D and 9 others (2014) Basal roughness of the institute and Möller ice streams, west Antarctica: process determination and landscape interpretation. Geomorphology 214, 139-147. doi: 10.1016/j.geomorph.2014.01.021.

Robin GdQ (1958) Glaciology III: Seismic Shooting and Related Investigations. Norsk Polarinstitutt, Tromso, Norway.

Robin GdQ (1975) Radio-echo sounding: glaciological interpretations and applications. Journal of Glaciology 15(73), 49-64. doi: 10.3189/ s0022143000034262.

Rodriguez-Morales F and 9 others (2013) Advanced multifrequency radar instrumentation for polar research. IEEE Transactions on Geoscience and Remote Sensing 52(5), 2824-2842. doi: 10.1109/TGRS.2013.2266415.

Romero-Wolf A and 5 others (2015) A passive probe for subsurface oceans and liquid water in Jupiter's icy moons. Icarus 248, 463-477. doi: 10. 1016/j.icarus.2014.10.043.
Romero-Wolf A and 7 others (2016) Prospects of passive radio detection of a subsurface ocean on Europa with a lander. Planetary and Space Science 129, 118-121. doi: 10.1016/j.pss.2016.06.010.

Ross N and Siegert M (2020) Basal melting over Subglacial Lake Ellsworth and its catchment: insights from englacial layering. Annals of Glaciology 61(81), 198-205. doi: 10.1017/aog.2020.50.

Ross $\mathbf{N}$ and 9 others (2012) Steep reverse bed slope at the grounding line of the Weddell Sea sector in West Antarctica. Nature Geoscience 5(6), 393396. doi: 10.1038/ngeo1468.

Rutishauser A and 8 others (2018) Discovery of a hypersaline subglacial lake complex beneath Devon Ice Cap, Canadian Arctic. Science Advances 4(4), eaar4353. doi: 10.1126/sciadv.aar4353.

Scanlan KM and 5 others (2019) Geometric determination of ionospheric total electron content from dual frequency radar sounding measurements. Planetary and Space Science 178, 104696. doi: 10.1016/j.pss.2019.07.010.

Scanlan KM, Rutishauser A, Young DA and Blankenship DD (2020) Interferometric discrimination of cross-track bed clutter in ice-penetrating radar sounding data. Annals of Glaciology 61(81), 68-73. doi: 10.1017/ aog.2020.20.

Schmidt B, Blankenship DD, Patterson G and Schenk P (2011) Active formation of chaos terrain over shallow subsurface water on Europa. Nature 479(7374), 502-505. doi: 10.1038/nature10608.

Schmidt LS, Hvidberg CS, Kim JR and Karlsson NB (2019) Non-linear flow modelling of a Martian Lobate Debris Apron. Journal of Glaciology 65(254), 889-899. doi: 10.1017/jog.2019.54.

Schroeder DM and 7 others (2016b) Assessing the potential for passive radio sounding of Europa and Ganymede with RIME and REASON. Planetary and Space Science 134, 52-60. doi: 10.1016/j.pss.2016.10.007.

Schroeder DM and 9 others (2019) Multidecadal observations of the Antarctic ice sheet from restored analog radar records. Proceedings of the National Academy of Sciences 116(38), 18867-18873. doi: 10.1073/pnas. 1821646116.

Schroeder DM, Blankenship DD, Raney RK and Grima C (2014a) Estimating subglacial water geometry using radar bed echo specularity: application to Thwaites Glacier, West Antarctica. IEEE Geoscience and Remote Sensing Letters 12(3), 443-447. doi: 10.1109/LGRS.2014.2337878.

Schroeder DM, Blankenship DD and Young DA (2013) Evidence for a water system transition beneath Thwaites Glacier, West Antarctica. Proceedings of the National Academy of Sciences 110(30), 12225-12228. doi: 10.1073/pnas. 1302828110 .

Schroeder DM, Blankenship DD, Young DA and Quartini E (2014b) Evidence for elevated and spatially variable geothermal flux beneath the West Antarctic ice sheet. Proceedings of the National Academy of Sciences 111(25), 9070-9072. doi: 10.1073/pnas.1405184111.

Schroeder DM, Blankenship DD, Young DA, Witus AE and Anderson JB (2014c) Airborne radar sounding evidence for deformable sediments and outcropping bedrock beneath Thwaites Glacier, West Antarctica. Geophysical Research Letters 41(20), 7200-7208. doi: 10.1002/2014GL061645.

Schroeder DM, Grima C and Blankenship DD (2016a) Evidence for variable grounding-zone and shear-margin basal conditions across Thwaites Glacier, West Antarctica. Geophysics 81(1), WA35-WA43. doi: 10.1190/ geo2015-0122.1.

Schroeder DM, Hilger AM, Paden JD, Young DA and Corr HF (2018) Ocean access beneath the southwest tributary of Pine Island Glacier, West Antarctica. Annals of Glaciology 59(76), 10-15. doi: 10.1017/aog.2017.45.

Schroeder DM, Seroussi H, Chu W and Young DA (2016c) Adaptively constraining radar attenuation and temperature across the Thwaites Glacier catchment using bed echoes. Journal of Glaciology 62(236), 1075-1082. doi: $10.1017 /$ jog.2016.100.

Sergienko O (2013) Basal channels on ice shelves. Journal of Geophysical Research: Earth Surface 118(3), 1342-1355. doi: 10.1002/jgrf.20105.

Seroussi H, Ivins ER, Wiens DA and Bondzio J (2017) Influence of a West Antarctic mantle plume on ice sheet basal conditions. Journal of Geophysical Research: Solid Earth 122(9), 7127-7155. doi: 10.1002/ 2017 JB014423.

Seu $\mathbf{R}$ and 11 others (2007) SHARAD sounding radar on the Mars Reconnaissance Orbiter. Journal of Geophysical Research E: Planets 112(5). doi: 10.1029/2006JE002745.

Shi L and 8 others (2010) Multichannel coherent radar depth sounder for NASA operation ice bridge. In 2010 IEEE International Geoscience and Remote Sensing Symposium. IEEE, Honolulu, Hawaii, pp. 1729-1732. doi: 10.1109/IGARSS.2010.5649518. 
Shoemaker IM and 5 others (2020) Reflections on the anomalous ANITA Events: the Antarctic subsurface as a possible explanation. Annals of Glaciology 61(81), 92-98. doi: 10.1017/aog.2020.19.

Siegert MJ (2003) Glacial-interglacial variations in central east Antarctic ice accumulation rates. Quaternary Science Reviews 22(5-7), 741-750. doi: 10. 1016/S0277-3791(02)00191-9.

Siegert MJ and 9 others (2004) Ice flow direction change in interior West Antarctica. Science (New York, N.Y.) 305, 1948-1951. doi: 10.1126/ science. 1101072 .

Siegert MJ and 7 others (2016) Subglacial controls on the flow of Institute Ice Stream, West Antarctica. Annals of Glaciology 57(73), 19-24. doi: 10.1017/ aog.2016.17.

Siegert MJ (2018) A 60-year international history of Antarctic subglacial lake exploration. Geological Society, London, Special Publications 461(1), 7-21. doi: $10.1144 /$ SP461.5

Siegfried MR, Fricker HA, Carter SP and Tulaczyk S (2016) Episodic ice velocity fluctuations triggered by a subglacial flood in West Antarctica. Geophysical Research Letters 43(6), 2640-2648. doi: 10.1002/ 2016 GL067758.

Sime LC, Hindmarsh RC and Corr H (2011) Automated processing to derive dip angles of englacial radar reflectors in ice sheets. Journal of Glaciology 57(202), 260-266. doi: 10.3189/002214311796405870.

Smith BE, Fricker HA, Joughin IR and Tulaczyk S (2009) An inventory of active subglacial lakes in Antarctica detected by ICESat (2003-2008). Journal of Glaciology 55(192), 573-595. doi: 10.3189/002214309789470879.

Smith IB, Putzig NE, Holt JW and Phillips RJ (2016) An ice age recorded in the polar deposits of Mars. Science (New York, N.Y.) 352, 1075-1078. doi: $10.1126 /$ science.aad6968.

Sorge E (1933) The scientific results of the Wegener expeditions to Greenland. The Geographical Journal 81(4), 333-344. doi: 10.2307/1785439.

Sori MM and Bramson AM (2019) Water on Mars, with a grain of salt: local heat anomalies are required for basal melting of ice at the South Pole today. Geophysical Research Letters 46(3), 1222-1231. doi: 10.1029/ 2018GL080985.

Spudis PD and 9 others (2013) Evidence for water ice on the Moon: results for anomalous polar craters from the LRO Mini-RF imaging radar. Journal of Geophysical Research: Planets 118(10), 2016-2029. doi: 10.1002/jgre. 20156.

Steenson BO (1951) Radar Methods for the Exploration of Glaciers ( $\mathrm{PhD}$ thesis). California Institute of Technology.

Steinbrügge G and 5 others (2018) Assessing the potential for measuring Europa's tidal love number h2 using radar sounder and topographic imager data. Earth and Planetary Science Letters 482, 334-341. doi: 10.1016/j.epsl. 2017.11.028.

Stern W (1930) Principles, methods and results of electrodynamic thickness measurement of glacier ice. Zeitschrift fur Gletscherkunde 18, 24.

Stewart CL, Christoffersen P, Nicholls KW, Williams MJ and Dowdeswell JA (2019) Basal melting of Ross Ice Shelf from solar heat absorption in an ice-front polynya. Nature Geoscience 12(6), 435-440. doi: 10.1038/s41561-019-0356-0.

Stillman DE, MacGregor JA and Grimm RE (2013) The role of acids in electrical conduction through ice. Journal of Geophysical Research: Earth Surface 118(1), 1-16. doi: 10.1029/2012JF002603.

Stuurman CM and 6 others (2016) SHARAD detection and characterization of subsurface water ice deposits in Utopia Planitia, Mars. Geophysical Research Letters 43(18), 9484-9491. doi: 10.1002/2016GL070138.

Tang XY, Guo JX, Sun B, Wang TT and Cui XB (2016) Ice thickness, internal layers, and surface and subglacial topography in the vicinity of Chinese Antarctic Taishan station in Princess Elizabeth Land, East Antarctica. Applied Geophysics 13(1), 203-208. doi: 10.1007/s11770-016-0540-6.

Tinto K and 9 others (2019) Ross Ice Shelf response to climate driven by the tectonic imprint on seafloor bathymetry. Nature Geoscience 12, 441-449. doi: 10.1038/s41561-019-0370-2.

Turchetti S, Dean K, Naylor S and Siegert M (2008) Accidents and opportunities: a history of the radio echo-sounding of Antarctica, 1958-79. The British Journal for the History of Science 41(3), 417-444. doi: 10.1017/ S0007087408000903.
Vankova I and 5 others (2020) Depth-dependent artifacts resulting from ApRES signal clipping. Annals of Glaciology 61(81), 108-113. doi: 10. 1017/aog.2020.56.

Vaughan DG and 9 others (2006) New boundary conditions for the West Antarctic ice sheet: Subglacial topography beneath Pine Island Glacier. Geophysical Research Letters 33(9), GL025561. doi: 10.1029/2005GL025588.

Waddington ED, Neumann TA, Koutnik MR, Marshall HP and Morse DL (2007) Inference of accumulation-rate patterns from deep layers in glaciers and ice sheets. Journal of Glaciology 53(183), 694-712.

Wang B and 6 others (2018) Summit of the East Antarctic ice sheet underlain by thick ice-crystal fabric layers linked to glacial-interglacial environmental change. Geological Society, London, Special Publications 461(1), 131-143. doi: $10.1144 /$ SP461.1.

Wang B and 9 others (2020) Removal of 'strip noise' in radio-echo sounding data using combined wavelet and 2-D DFT filtering. Annals of Glaciology 61(81), 124-134. doi: 10.1017/aog.2019.4.

Warner RC and Budd W (2000) Derivation of ice thickness and bedrock topography in data-gap regions over Antarctica. Annals of Glaciology 31, 191-197. doi: 10.3189/172756400781820011.

Whitten JL, Campbell BA and Morgan GA (2017) A subsurface depocenter in the South Polar Layered Deposits of Mars. Geophysical Research Letters 44(16), 8188-8195. doi: 10.1002/2017GL074069.

Winter A and 9 others (2017) Comparison of measurements from different radio-echo sounding systems and synchronization with the ice core at Dome C, Antarctica. The Cryosphere 11(1), 653-668. doi: 10.5194/tc-11-653-2017.

Winter K and 10 others (2019) Radar-detected englacial debris in the West Antarctic ice sheet. Geophysical Research Letters 46(10), 10454-10462. doi: 10.1029/2019GL084012.

Winter A, Steinhage D, Creyts TT, Kleiner T and Eisen O (2019) Age stratigraphy in the East Antarctic ice sheet inferred from radio-echo sounding horizons. Earth System Science Data 11(3), 1069-1081. doi: 10.5194/ essd-11-1069-2019.

Wolovick MJ, Bell RE, Creyts TT and Frearson N (2013) Identification and control of subglacial water networks under Dome A, Antarctica. Journal of Geophysical Research: Earth Surface 118(1), 140-154. doi: 10.1029/ 2012JF002555.

Wright A and Siegert M (2012) A fourth inventory of Antarctic subglacial lakes. Antarctic Science 24(6), 659-664. doi: 10.1017/S095410201200048X.

Wrona T and 5 others (2017) Position and variability of complex structures in the central East Antarctic ice sheet. In Siegert M, Jamieson S and White D (eds), Exploration of Subsurface Antarctica: Uncovering Past Changes and Modern Processes, number 461 in Special Publication. Geological Society of London, pp. 113-129. doi: 10.1144/SP461.12.

Wu X and 5 others (2011) Ice sheet bed mapping with airborne SAR tomography. IEEE Transactions on Geoscience and Remote Sensing 49(10), 37913802. doi: 10.1109/TGRS.2011.2132802.

Xiong S and Muller JP (2019) Automated reconstruction of subsurface interfaces in Promethei Lingula near the Martian south pole by using SHARAD data. Planetary and Space Science 166, 59-69. doi: 10.1016/j.pss.2018.08.001.

Xiong S, Muller JP and Carretero RC (2018) A new method for automatically tracing englacial layers from MCoRDS data in NW Greenland. Remote Sensing 10(1). doi: 10.3390/rs10010043.

Yan JB, Gogineni P and O’Neill C (2018) L-band radar sounder for measuring ice basal conditions and ice-shelf melt rate. In IGARSS 2018-2018 IEEE International Geoscience and Remote Sensing Symposium. IEEE, Valencia, Spain, pp. 4135-4137. doi: 10.1109/IGARSS.2018.8518210.

Young DA and 9 others (2011) A dynamic early East Antarctic ice sheet suggested by ice-covered fjord landscapes. Nature 474(7349), 72-75. doi: 10 1038 /nature10114

Young TJ and 8 others (2018) Resolving the internal and basal geometry of ice masses using imaging phase-sensitive radar. Journal of Glaciology 64 (246), 649-660. doi: 10.1017/jog.2018.54.

Young DA, Schroeder D, Blankenship DD, Kempf SD and Quartini E (2016) The distribution of basal water between Antarctic subglacial lakes from radar sounding. Philosophical Transactions of the Royal Society A: Mathematical, Physical and Engineering Sciences 374(2059), 20140297. doi: 10.1098/rsta.2014.0297. 